\title{
1 Cirripedes (Thoracica, Crustacea) from the Maastrichtian of Kalaat
}

\section{Senan, Tunisia}

\section{Andy S. Gale ${ }^{\text {a,b, }}$, John W. M. Jagt ${ }^{\text {, }}$, Stijn Goolaerts ${ }^{\text {d,e }}$}

4

$5{ }^{a, b}$ School of Environmental, Geological and Geographical Sciences, University of Portsmouth,

6 Burnaby Building, Burnaby Road, Portsmouth PO13QL, and Earth Science Department,

7 Natural History Museum, Cromwell Road, London SW75BD, United Kingdom

$8{ }^{\mathrm{C}}$ Natuurhistorisch Museum Maastricht, de Bosquetplein 6-7, 6211 KJ Maastricht, the

$9 \quad$ Netherlands

10 d,e Department of Earth \& History of Life, and Scientific Service Heritage, Royal Belgian Institute of Natural Sciences, Vautierstraat 29, 1000 Brussels, Belgium

* Corresponding author.

14 E-mail address: andy.gale@port.ac.uk (A.S. Gale).

\section{A B S T R A C T}

An assemblage of large and robust pedunculate scalpellomorph cirripede barnacles from the Maastrichtian of Kalaat Senan (Tunisia) is described, and their stratigraphical position within the Abiod and El Haria formations is noted. Four taxa are documented, three of which are confined to the Kalaat Senan area, namely Pachyscalpellum heltzeli, Cretiscalpellum robaszynskii sp. nov. and Diotascalpellum sp.; the fourth, Diotascalpellum curvatum, was previously recorded only from the Maastrichtian of the Farafra Oasis in the 
24 Western Desert of Egypt, 2,000 kilometres to the southeast. The record of Pollicipes glaber

25 from this locality may well be conspecific with $C$. robaszynskii sp. nov. The new finds yield

26 clues to the evolution of the composition of the North African cirripede assemblages during

27 the early and late Maastrichtian, up close to the Cretaceous-Paleogene (K/Pg) boundary

28 mass extinction. The fauna is of remarkably large size and strongly armoured for the supposedly offshore open-marine palaeoenvironment of Kalaat Senan, a faunal character

30 that seems to have developed after the Campanian and disappeared by the Danian. The presence of Pachyscalpellum, a genus that was previously restricted to Australasia, indicates

32 faunal connections with the eastern Tethys. Their documented first arrival coincides roughly with the first documented occurrence of northern American scaphitid ammonite genus Discoscaphites. The original description of $P$. heltzeli is extended; it is characterised particularly by a very elongated scutum. Similar scuta are shown to have evolved independently in the scalpellid genus Regioscalpellum of the European Upper Cretaceous.

37 The family assignment of Pachyscalpellum as a scalpellid is questioned.

38

39 40

41 Key words:

42 Cirripedia

43 Cretaceous

$44 \mathrm{~K} / \mathrm{Pg}$ boundary extinction

45 faunal changes

\section{$47 \quad$ 1. Introduction}


The exquisitely exposed, 5,000-m-thick and nearly continuous fossiliferous sedimentary

50

51

53

54

55

56

57

58 sequence spanning the Aptian up to the Eocene near the village of Kalaat Senan, central

Tunisia (Fig. 1), has attracted geologists and palaeontologists from as early as the last quarter of the nineteenth century. During that time, the French geologist Georges Rolland directed the geological branch of Ernest Cosson's exploratory scientific missions in Tunisia. It was Rolland himself who focused on the geology of central Tunisia, aided by the vet and amateur geologist, Philippe Thomas, in palaeontological research (Godard \& Viaud, 2007). The most important geologist and palaeontologist of the early days by far was the Frenchman Léon Pervinquière (1873-1913), whose fieldwork from 1897 onwards culminated in an in-depth study of the geology of central Tunisia (Pervinquière, 1903), followed by detailed studies of Cretaceous cephalopods (Pervinquière, 1907) and bivalves and gastropods (Pervinquière, 1912). Philippe Thomas finished his manuscript only in 1909 and clearly incorporated many of Pervinquière's observations. Pervinquière's untimely death left a huge hiatus in studies of macrofossils from the Kalaat Senan area, even when shortly after the Second World War, the 'Société de Recherches et d'Exploitation des Pétroles en Tunisie' (SEREPT) had considerable interest in logging sections (judging from numerous unpublished reports), followed by mapping (Lehotsky et al., 1978) and studies primarily focused on microfauna and long-distance correlations (for an overview, see Robaszynski et al., 2000). Only in 1985, when the SEREPT, the 'Société Nationale Elf Acquitaine Productions' (SNEAP) and EXXON Production and Research sent out an interdisciplinary team of stratigraphers, led by Professor Francis Robaszynski, to log in detail and describe the rocks exposed between Kalaat Senan, Tajerouine and Kalaa Khasba, would stratigraphical collection of macrofossils be resumed. The Cenomanian to Maastrichtian sequences were recorded by Robaszynski et al. (1990, 1993a-c, 2000, 2007) and Hardenbol 
et al. (1993), the K/Pg boundary interval by Dupuis et al. (2001), Hennebert and Dupuis (2003) and Hennebert (2012) and the Danian/Selandian boundary interval by Steurbaut et al. (2000). From 2001 to 2005, one of us (SG), under the guidance of professors Christian Dupuis, Etienne Steurbaut and Francis Robaszynski, did extensive collecting of macrofossils in Campanian and Maastrichtian strata at Kalaat Senan (as well as at Ellès, El Kef and Garn Halfaya), which resulted in papers on ammonite evolution and extinction (Goolaerts et al., 2004a, b; Goolaerts, 2010; Landman et al., 2014, 2015), and on a new isopod crustacean (Feldmann and Goolaerts, 2005). Of cirripedes, 42 dissociated plates were collected; these are the subject of the present paper. Added were three specimens, recovered in 1995 within the framework of the MSc thesis by Bénédicte Eggermont. For now, echinoids, crinoids, serpulid polychaetes, bryozoans, bivalves, gastropods, brachiopods and corals remain largely unstudied.

Of the 45 cirripede plates, 25 were described in Jagt et al. (2016) as belonging to a new species, Pachyscalpellum heltzeli. Most probably, records by Peron (1893, p. 385, from the southern regions of the 'Hauts Plateaux de la Tunisie'), Pervinquière (1903, p. 132, from the upper Maastrichtian of Djebel Massouge) and Thomas (1909, pp. 670-671, from the upper Maastrichtian of Kalaat Senan) all relate to $P$. heltzeli (compare Jagt et al., 2016). Buckeridge et al. (2008) described a new species of verrucomorph, Verruca punica, and noted the presence of scalpellomorph cirripedes, probably belonging to Calantica or Scillaelepas, from the lower Danian (NP2, P1b) portion of the El Haria Formation at El Kef. A few years earlier, Collins et al. (1999) had already described a new stalked form, Arcoscalpellum gloriana, from the upper Ypresian (Eocene) of Fedj Merabitha near Kairouan. 


\section{Geographical and stratigraphical setting}

98

99

100

101

102

103

104

105

106

107

108

109

110

111

112

113

114

115

116

117

118

119

120

Material was collected from outcrops of Maastrichtian rocks situated between the

villages of Kalaat Senan, Tajerouine and Khalaa Khasba in central Tunisia, also known as the

Kalaat Senan area (Fig. 1). Detailed descriptions, lithologs and a composite section were published by Robaszynski et al. (2000) and Goolaerts (2010). The best-known sequence in this area by far is the K/Pg boundary section of Aïn Settara (abbreviation STW), an auxiliary section of the El Kef GSSP for the base of the Danian/Paleocene/Paleogene (Dupuis et al., 2001; Hennebert and Dupuis, 2003; Molina et al., 2009; Hennebert, 2012). Outcrops from which cirripedes were collected are situated in two clusters (Fig. 2), the Oued Raïne outcrops with the RB, RC, and RCN sections forming the first cluster and the STW and NCH sections located in the second.

Strata exposed at the Oued Raïne and STW sections have been assigned to the El Haria Formation for which two informal units can be distinguished. The lower of these (Mzita marls), around 60 metres in thickness, comprises light greyish to bluish grey marls, with intercalated 30-50-cm-thick, slightly reddish limestone beds in two intervals. The thickness of the upper unit, the Aïn Settara marls, is 128 metres. These are grey marls alternating with marly, lighter-coloured intervals that are richer in carbonate. Strata exposed at the NCH section represent the Gourbeuj, Ncham and Gouss members of the Abiod Formation and the Mzita marls of the El Haria Formation. In the NCH section, cirripedes were found only in the Ncham Member.

In addition to the above specimens, no cirripedes were found by us in Campanian strata of the Kalaat Senan area, nor in the Campanian-Maastrichtian interval of El Kef, Ellès and Garn Halfaya. Although some collection bias (as the primary field targets were 
cephalopods) may be assumed, the large and robust cirripede valves would have been

122 noted if such had been as abundant as at Kalaat Senan. In addition, no cirripede remains

123 were found in sieving residues of (relatively limited) quantities of sediment of the upper

124 metre below the K/Pg boundary at El Kef (Goolaerts, 2010).

125

\section{3. Material and methods}

In total, 45 dissociated cirripede plates from 26 samples (labelled TUC) are available

129 (a composite lot, numbered NHMM 2015 020, for Pachyscalpellum heltzeli [with letter

130 suffixes] and other NHMM numbers, as added to illustrations here), the great majority of

which stem from float (Table 1). For each of these specimens, the maximum stratigraphical

132 provenance was carefully estimated based on outcrop conditions (see Figs. 2, 3). Most plates in this lot are free from matrix and well preserved, yet incomplete. Photographs were taken of selected specimens. To denote the repositories of specimens illustrated and/or referred to in the text, the following abbreviations are used: NHMM, Natuurhistorisch Museum Maastricht,

137 Maastricht, the Netherlands; NHMUK, The Natural History Museum, London, United Kingdom; WAM, Western Australian Museum, Perth, Australia.

\section{Systematic palaeontology}


Diagnosis. Pedunculate thoracicans which possess 17 plates in the capitulum (paired scuta,

145 terga, upper latera, inframedian latera, rostrolatera, upper carinolatera (Cl1), lower

146 carinolatera ( $\mathrm{Cl} 2)$, carina, rostrum and subcarina); upper carinolatus rectangular to

147 rhomboidal, lower triangular. Peduncular plates relatively large, in 8 to 12 columns, with an

148 inwardly directed basal ledge.

149

150 Genera included. Cretiscalpellum Withers, 1922, Striascalpellum Gale, 2020,

151 Witherscalpellum Gale, 2020 and Jagtscalpellum Gale, 2020.

152

153 Genus Cretiscalpellum Withers, 1922

154

155 Type species. Pollicipes unguis J. de C. Sowerby, 1836, by original designation.

156

157 Diagnosis: Smooth to weakly sculptured large cretiscalpellids, in which the tergum is asymmetrically rhomboidal with a low, straight apicobasal ridge. Carinolatera, inframedian

159 latus and rostrolatus convex, bearing an oblique transverse ridge.

160

161 Other species included. Pollicipes glabra Roemer, 1841, Polliceps bronni Roemer, 1841,

162 Scalpellum longissimum Withers, 1911, Scalpellum paucistriatum Woodward, 1906, C.

163 obtusum Jagt and Collins, 1989 and C. mutterlosei Gale, 2019.

Cretiscalpellum robaszynskii sp. nov.

Figs. 5A-C, G-J, 6A, B 
172 Diagnosis. Very large, robust species of Cretiscalpellum in which the carina is long and 173 tapers slowly; surface of tergum divided by apicobasal line into depressed carinal surface 174 and raised scutal surface; scutum with acute basitergal angle.

175

176 Types. The holotype, a carina, is NHMM 2019026 (Fig. 5G-I); other plates illustrated are 177 paratypes. These include a carina (NHMM 2019 027; Fig. 5J), three terga (NHMM 2019 028178 030; Fig. 5A-C) and a fragmentary scutum (NHMM 2019 031; Fig. 6A, B).

179

Material. Types, plus some fragmentary specimens (Table 1).

181 Etymology. Named after Dr Francis Robaszynski, Professor emeritus of the Université de Mons (Belgium), eminent stratigrapher, micropalaeontologist and field geologist, for his tireless efforts in the study of the Cretaceous as a whole and the Tunisian Cretaceous in particular.

Type locality and horizon. Oued Raïne (RC section), Kalaat Senan area, central Tunisia (Fig.

187 1); El Haria Formation, lowermost Aïn Settara marls, lower part of calcareous nannoplankton zone CC26, upper Maastrichtian (Fig. 2).

Description. The carina (Fig. 5G-I, J) is tall and tapers slowly, with an apical angle of $16^{\circ}$. In

191 lateral aspect, the dorsal margin is gently convex, the ventral margin concave. The surface sculpture comprises evenly spaced, low commarginal ridges, separated by regions with 
numerous, indistinct minor ridges. A narrow apicobasal ridge is present, which carries low nodes where it intersects with the growth increments. The incomplete terga (Fig. 5A-C) are symmetrically rhombic in outline and the upper carinal/occludent margins are slightly shorter than the lower carinal/scutal margins. The straight apicobasal line separates a slightly depressed carinal portion of the valve surface from the raised scutal surface. The sculpture comprises low, irregular ridges separating successive growth increments; in some specimens (e.g., Fig. 5A) minor ridges are bundled between larger ridges, paralleling the sculpture of the carinae, whereas in others (Fig. 5B) the arrangement is more irregular. A slightly raised region, subparallel with the occludent margin, articulated with the tergal notch on the scutum. In one specimen, the region dorsal to the scutal margin is depressed and bears weak radial sculpture (Fig. 5C). Only a single, fragmentary scutum has been found, representing the basal portion of the valve (Fig. 6A, B). This has a relatively acute basitergal angle and a slightly obtuse rostral angle. The dorsal part of the valve carries a weak radial sculpture.

Remarks. Wanner (1902, p. 145) described and figured a carina from (pl. 29 fig. 23) from the Bab-el-Jasmund section (Egypt) as Pollicipes glaber. He also mentions two fragmentary terga from the uppermost Cretaceous (obersten Kreide) of the Farafrah Oasis, to the east of

211 Farafrah, Egypt. It is very likely that the carina figured by Wanner is conspecific with $C$.

212 robaszynskii sp. nov. This species differs from C. glabrum (Fig. 6E) in the significantly narrower, longer carina (apical angle $16^{\circ} ; 21-25^{\circ}$ in $C$. glabrum) and the evenly spaced low nodes on the narrow apicobasal ridge. The external surface of the carina has a very weak radial sculpture, absent in C. glabrum. It differs from C. filosum, which has an elongated carina, in the absence of a grooved apicobasal ridge on the tergum (Withers, 1935, pl. 19, 
figs. 9, 10). The terga of $C$. robaszynskii sp. nov. differ from those of $C$. glabrum (Fig. 6G) in

218 the less well-defined scutal articulation surface. They differ from those of $C$. paucistriatum

219 (Fig. 6F) in the straight, rather than gently convex, lower carinal margin. The scuta of $C$.

220 robaszynskii sp. nov. differ from those of $C$. glabrum and C. paucistriatum (Fig. 6C) in the

221 more acute basitergal angle and obtuse rostral angle.

222

223 Family Scalpellidae Pilsbry, 1916

224 Genus Diotascalpellum Gale, 2015

225

226

Type species. Scalpellum diota Hoek, 1907, by original designation.

227

228

Diagnosis. Scalpellids in which there is no specialised contact between the carina and

carinolatus, merely a crescentic concavity on the interior of the plate which forms a rim

slightly overlapping the upper latus; umbo of carinolatus upright, only slightly incurved, dorsal margin gently convex; inframedian surface of carinolatus well demarcated and slightly inset.

Other species included. Scalpellum rubrum Hoek, 1883, Scalpellum indicum Hoek, 1883, Pollicipes angustatus Geinitz, 1843, Scalpellum gracile Bosquet, 1854 and Scalpellum fossula Darwin, 1851.

Remarks. The genus Diotascalpellum was founded largely upon the morphology of the carinolatus and its contact with the carina, and certain assignation of species to the genus in the absence of carinolatera is not easy. However, the one known articulated specimen of $D$. 
241 fossula (Darwin, 1851; NHMUK In. 30455, the original of Withers, 1935, pl. 26, fig. 3) and

242 that of $D$. angustatum (Geinitz, 1843; see Kočova Veselská et al., 2020, fig. 4) show the form

243 of the capitulum well, in particular, the morphology of the carinae. The tectum is flat, bears

244 basally $\mathrm{V}$-ing regular growth increments and is separated from the parietes by a ridge; the

245 intraparietes are inset and crescentic and extend along the apical 25-35 per cent length of

246 the valve. The presence of a number of these features in Scalpellum curvatum Wanner,

247 1902, permits assignment to Diotascalpellum (see below).

248

249 Diotascalpellum curvatum (Wanner, 1902)

250 Fig. $5 K-Q$

251

252

*1902 Scalpellum curvatum Wanner, p. 146, pl. 19, figs. 24-27.

1935 Scalpellum (Arcoscalpellum) curvatum Wanner; Withers, p. 273, pl. 34, figs. 12-16.

Diagnosis. A species of Diotascalpellum in which the intraparietes are very narrow and separated from the parietes by a ridge.

257

258 Types. The carina figured by Wanner (1902, pl. 19, fig. 12 see above) was designated lectotype by Withers (1935, p. 273); the other illustrated can be considered paralectotypes. The material described by Wanner (1902) was collected by Karl von Zittel during his exploratory missions in 1873-1874 'in den obersten Kreideschichten vom Bâb-el-Jasmund bei Dachel und in der Nachbarschaft des Dorfes Farâfrah'. Bab-el-Jasmund is the southern entry point (Bab meaning port) of the Fafafra Oasis after crossing the Naqb-el-Qsar Pass coming from Dakhla (Dahel) in the Egyptian Western Desert (in Wanner's [1902] time 'die 
Lybische Wüste'), a spectacular opening between rocks that received its name from Rohlfs in 1874. The 'oberste[n] Kreideschichten' are most probably of Maastrichtian or Paleocene age and are represented today by the Khoman and/or lower part of the Dakhla formations (Hewaidy et al., 2006). Both Wanner (1902) and Withers (1935) stated that the specimens were housed in the collections of the Geologisches-Paläontologisches Museum in München, Germany.

Material. One tergum (NHMM 2019 032; Fig. 5P), three scuta (NHMM 2019 033-035; Fig. 5K, L, M, Q) and a single carina (NHMM 2019 036; Fig. 5N, O) (Table 1).

Description. The carina (Fig. $5 \mathrm{~N}, \mathrm{O}$ ) is strongly inclined ventrally and the dorsal margin is strongly and evenly convex. The tectum is arched about the axis of the plate and apically bears a sharp median ridge, and is separated from the inflected parietes by symmetrical, rounded ridges. The surface of the tectum carries basally $\mathrm{V}$-ing, evenly spaced grooves marking successive growth increments. The narrow intraparietes are separated from the parietes by a rounded, raised ridge. The tergum (Fig. 5P) is rhombic and the broader, occludent, ventral part of the valve is separated from the dorsal part by a gently curved apicobasal line. The lower carinal margin is convex, the upper carinal margin straight, the occludent margin slightly concave. The sculpture of the dorsal surface comprises evenly spaced, curved ridges which run from the apicobasal line to the upper carinal margin. The ventral surface is centrally depressed, and carries weaker commarginal ridges, restricted to the ventral portion, and weak radial lineation. The scuta (Fig. 5K, L, M, Q) are subrectangular in outline and the rostral and basitergal angles are close to $90^{\circ}$; the occludent margin is gently convex. The tergal margin subtends an angle of $60^{\circ}$ to the occludent margin and the 
curved apicobasal line separates a rather smooth, triangular, tergal surface from the occludent surface. This bears evenly spaced, slightly sinuous, coarse ridges which run from

291 the apicobasal ridge to the tergal margin. The similarity of sculpture on the carna, tergum and scutum confirm the conspecifity of the different valves.

293

294 Remarks. The new material is closely similar to Wanner's original specimens, as illustrated 295 by Withers (1935). Diotascalpellum curvatum differs from the closely related species $D$. fossula and $D$. angustatum principally in the unusual ridged separation of the parietes and

297 the very narrow intraparietes.

298

Diotascalpellum sp.

300

Fig. 5D-F

301

302

Material. A single fragmentary carina, NHMM 2019037 (Table 1).

303

304

Description. The tectum is broad, weakly ridged, bearing rather irregular, basally V-ing

305 growth increments. The separation between the tectum and the parietes is a simply angled one; the intraparietes and parietes are separated by a low, rounded ridge. The intraparietes are broad and crescentic in lateral aspect.

Remarks. The absence of a strong ridge separating the tectum and the parietes and the broad intraparieties separate this form from Diotascalpellum curvatum, as does the broad tectum bearing irregular growth increments. The absence of the ridge between the tectum

312 and parietes distinguishes this specimen from material of $D$. angustatum and $D$. fossula. 
314 Family uncertain

315 Genus Pachyscalpellum Buckeridge, 1991

316

317 Type species. Pachyscalpellum cramptoni Buckeridge, 1991, by original designation.

319 Diagnosis. Valves thickened, robust; scutum triangular, tergum bifid with excavated scutal margin.

Other species included. Pachyscalpellum debodae Buckeridge, 1999, Pollicipes glauerti

Withers, 1926 and Pachyscalpellum heltzeli Jagt, Verhesen and Goolaerts, 2016.

Remarks. Although material of $P$. heltzeli was described in detail by Jagt et al. (2016), not all specimens were illustrated, including some interesting material which has a bearing on the relationships of the genus. Additionally, although Pachyscalpellum has generally been assigned to the family Scalpellidae (Buckeridge, 1991, 1999; Jagt et al. 2016), as a form convergent in its reduced, bifid tergum with genera such as the extant genus Neoscalpellum

330 Pilsbry, 1907, the structure of the carina in particular differs significantly from fossil and 331 living scalpellids. Newman (1996) and Jones and Hosie (2008) refer Pachyscalpellum to the

\section{Calanticidae.}

In scalpellids, there is consistent separation of the external surfaces of the carina

334 into a dorsal, flat or arched, tectum, with an angled separation from the lateral (dorsally directed) paired surfaces called parietes. In turn, these are separated from two surfaces called intraparietes (Darwin, 1851; Withers, 1935) which bear growth lines with an 
orientation subparallel to the length of the valve; intraparietes are not always present in scalpellids. Forms basal to the scalpellids lack true parietes and intraparietes and include zeugmatolepadids (Fig. 4D-F), calanticids (Fig. 4A, C) and cretiscalpellids (Fig. 4B), a selection of which are illustrated here. In these, the carina is rounded in transverse cross section, with or without a narrow external median ridge. Additionally, in scalpellids, the

342 growth increments on the external surface of the carina (tectum) either $V$ towards the base

343 of the valve (Fig. 4G, H) or are straight and transverse (Fig. 4I-L); in more basal taxa these

344 are more and less strongly convex towards the basal margin. In Pachyscalpellum (Fig. 8)

345 parietes and intraparietes are absent and the external growth increments are shallowly

346 rounded and extend to the ventral margins of the valves. On the evidence of the carinal

347 morphology, it seems possible that Pachyscalpellum was derived from a basal scalpellomorph, such as a calanticid, by reduction of the tergum to a bifid structure, in parallel with the more extreme reductions seen in Neoscalpellum and some other extant 350 deep-water scalpellids. The species Calantica? saskatchwanensis Russell, 1967, from the

351 Campanian Bearpaw Formation of Canada also bears comparison with Pachyscalpellum in

352 its possession very large, robust valves, including elongated scuta with acute apical and rostral angles. More detailed comparison must, however, await redescription of the original material.

Pachyscalpellum heltzeli Jagt, Verhesen and Goolaerts, 2016

Figs. $7 \mathrm{~A}-\mathrm{N}, 8 \mathrm{~A}-\mathrm{O}$

Diagnosis. Pachyscalpellum in which the scutum is elongated, with a straight occludent margin; tergum bifid, with a central and an occludent wing. 
362 Types. The holotype is an incomplete right tergum, NHMM 2015 020w (Fig. 7M, N);

363 paratype is another fragmentary right tergum, NHMM 2015 020q (Fig. 7K, L).

364

365

Material. Seven scuta, two right terga (holotype and paratype) and 16 carinae, all contained 366 in the NHMM collections (Table 1).

367

Description. The scuta (Fig. 7A-J) are very robust and elongated, triangular, with a straight occludent margin and a convex tergal-lateral margin. The smallest specimens found (Fig. 7l, J) have an acute rostral angle $\left(65^{\circ}\right)$ and an obtuse basitergal angle $\left(115^{\circ}\right)$ and resemble ordinary cretiscalpellid and scalpellid scuta. With increased size, the ventral and apical portions of the valve elongate greatly, reducing the rostral angle to $25^{\circ}$ and increasing the basitergal angle to $130^{\circ}$. The terga, although broken (Fig. 7K-M) are bifid and possess a median process and a process parallel to the occludent margin. The carinae (Fig. 8A-O) are elongated and taper slowly to the apex. The dorsal surface is rounded and parietes are absent; growth lines are convex. In one very large specimen (Fig. 8M-O), the carina tapers to the basal margin.

Remarks. Of the described species to date, $P$. heltzeli is closest to $P$. glauerti from the upper Santonian of Western Australia (Withers, 1935, pl. 9, figs. 3-6), in its elongated scutum and strongly bifid tergum. Indeed, the terga are very similar in the two species and the scuta can only be distinguished by the consistently straight occludent margin in P. heltzeli; this is gently convex in P. glauerti. The scuta in these species have a very unusual morphology, in their possession of an elongated occludent-basal region with an acute rostral angle. This is 
paralleled by scuta from the upper Campanian Norwich Chalk in the United Kingdom (Fig.

9D, E), which have a broadly similar shape to those of $P$. heltzeli, and as in that species,

387 developed ontogenetically from a more "upright" juvenile morphology (Fig. 9F-K). The

Norwich scuta are associated with carinae in which the apical portion of the valve adjacent

to the intraparietes is greatly thickened (Fig. 9P-R), for which the name Scalpellum

390

maximum var. cylindricum Darwin, 1851 is available. The structure of the carinae (presence

of parietes, intraparietes) and the scutum (elongated embayment for dwarf males) indicate

affinity with the genus Regioscalpellum Gale, 2015. It would appear to represent a parallel

evolutionary development of the scutum to that seen in Pachyscalpellum. The unique

\section{Concluding remarks}

401 exclusively of large and robust pedunculate scalpellomorphs. It includes four species, three of which are currently confined to this area, namely Pachyscalpellum heltzeli,

405 Cretiscalpellum robaszynskii sp. nov. and Diotascalpellum sp., and one which has previously been recorded only from the Maastrichtian of the Egyptian Western Desert, Diotascalpellum curvatum, more than 2,000 kilometres away. 
In the absence of wet sieving of matrix samples, it is probable that the stratigraphical ranges

410 of the species are currently underestimated, and that small species were completely

411 overlooked. The same method of collecting was applied to the Campanian and lower

412 Paleogene part of the sequence; no cirripede remains were found. In addition, the

413 Campanian and Maastrichtian intervals at Ellès, El Kef and Garn Halfaya, and some limited

414 sieving in the last metre below the $\mathrm{K} / \mathrm{Pg}$ boundary at El Kef did not yield any cirripede plates 415 either.

The stratigraphical range of the four species (Fig. 3) reveals that the fauna of the

417 lower Maastrichtian is slightly different from that of the upper and uppermost

Maastrichtian. From the Abiod Formation only D. curvatum is now recorded. Assemblages are most diverse in the lower part of the Aïn Settara marls (El Haria Formation), where $D$. curvatum, $C$. robaszynkii sp. nov. and $P$. heltzeli co-occur. Diotascalpellum curvatum and $C$. robaszynskii sp. nov. are not known from the uppermost metres below the K/Pg boundary.

422 None of the large species were found above the K/Pg boundary, and the only other Tunisian

423 cirripede record to date for the lower Danian (at El Kef; see Buckeridge et al. 2008)

424 documents a different fauna.

Pachyscalpellum is a genus that had previously been recorded exclusively from the

426 Australasian Upper Cretaceous (Santonian to Maastrichtian). The similarity between the

427 Tunisian P. heltzeli and P. glauerti from the Santonian of Western Australia is remarkable

428 and indicates that the genus had a wide distribution in the eastern Tethys (Jagt et al., 2016).

429 Its documented first appearance in the fossil record of Tunisia almost coincides with that of representatives of the North American scaphitid genus Discoscaphites Meek, 1870 
432 St. Antony, Egyptian Eastern Desert; Goolaerts, 2010; note that the exact age of Di.

433 kambysis at Ammonite Hill near Abu Minqarand Gbel Tarruân, Kharga Oasis, Western Desert 434 of Quaas (1902) is unknown).

435 The original description of $P$. heltzeli is here extended; it is characterised particularly

436 by a very elongated scutum. Similar scuta are shown to have evolved independently in the

437 scalpellid genus Regioscalpellum of the European Upper Cretaceous. The family assignation

438 of Pachyscalpellum as a scalpellid is questioned. The large and robust character is

439 exceptional for an offshore open-marine environment; such strongly armoured forms are

440 generally typical of shallower, more energetic, inshore environments. However, the

441 palaeogeographical position of Kalaat Senan, at the articulation of the southern shallower-

442 water carbonate platform and the northern more basinal basin, and with a marked

443 subsidence allowing a pelagic depositional environment but still sufficiently close positioned

444 to the platform to register various faunas of the shallower-water domain (Robaszynski et al.,

4452000 ) may explain this character of the cirripede assemblage described, as well as the

446 absence from other sites which are, certainly for El Kef, generally considered to be of more

447 deeper-water settings. The predominance and decreasing character noted among

448 Scaphitidae along the transect from Kalaat Senan over Garn Halfaya to El Kef within

449 ammonite assemblages in the uppermost Maastrichtian Indoscaphites AZ (from 76 to 60 , to

45048 per cent) also hints at a depth increase along this transect (Goolaerts et al., 2004b;

451 Goolaerts, 2010). Alternatively, with at least one species in common with the Farafra Oasis

452 in the Egyptian Western Desert, the large and robust character may be specific for

453 Maastrichtian cirripede assemblages of North Africa. This underpins again the great value of

454 the study of the sedimentary and faunal records of the Kalaat Senan area and, by extension, 
Paleogene ecosystem changes.

457

458 Acknowledgements

459

460

One of us (SG) wishes to thank Mohadine Yahia (Kalaat Senan), Prof. em. Etienne

461

Steurbaut (Royal Belgian Institute of Natural Sciences [KBIN-IRSNB-RBINS] and KULeuven,

462 Belgium), Prof. em. Christian Dupuis, Prof. em. Francis Robaszynski and Dr Michel

463 Hennebert (all Université de Mons, Mons, Belgium) for assistance in the field. Fossil

464 collecting was facilitated by financial aid from the Agency for Innovation by Science and

465 Technology (IWT; specialisation scholarship 13201). SG received additional financial

466

supported from Belspo BRAIN BR/175/A2/CHICXULUB project ‘Chicxulub 2016 IODP-ICDP

467

deep drilling: from cratering to mass-extinction'.

468

469

470

\section{References}

471

472 Bosquet, J., 1854. Les crustacés fossiles du terrain crétacé du Limbourg. Verhandelingen

473 uitgegeven door de Commissie belast met het vervaardigen eener geologische kaart

474 en beschrijving van Nederland 2, 1-127 [10-137].

475 Buckeridge, J.S., 1983. The fossil barnacles (Cirripedia: Thoracica) of New Zealand and 476 Australia. New Zealand Geological Survey, Palaeontological Bulletin 50, 1-152. 
477 Buckeridge, J.S., 1991. Pachyscalpellum cramptoni: a new genus and species of

478

479

480

481

482

483

484

485

486

487

488

489

490

491

492

493

494

495

496

497

498

499 lepadomorph cirripede from the Cretaceous of northern Hawke's Bay, New Zealand. Journal of the Royal Society of New Zealand 21, 55-60.

Buckeridge, J.S., 1999. Post Cretaceous biotic recovery: a case study on (Crustacea: Cirripedia) from the Chatham Islands, New Zealand. Records of the Canterbury Museum 13, 43-51.

Buckeridge, J.S., Jagt, J.W.M., Speijer, R.P., 2008. Verruca punica, a new species of verrucomorph barnacle (Crustacea, Cirripedia, Thoracica) from the Lower Danian (Palaeocene) of Tunisia. Zootaxa 1844, 37-46.

Collins, J.S.H., Moody, R.T.J., Sandman, R.I., 1999. A new crab and cirripede (Crustacea, Decapoda: Cirripedia) from the Upper Ypresian of central Tunisia. Bulletin of the Mizunami Fossil Museum 26, 121-127.

Darwin, C.R., 1851. A monograph on the sub-class Cirripedia, with figures of all the species. The Lepadidae, or pedunculated crripedes. The Ray Society, London, xii + 1-400, 10 pls.

Dupuis, C., Steurbaut, E., Molina, E., Rauscher, R., de Tribovillard, N., Arenillas, I., Arz, J.A., Robaszynski, F., Caron, M., Robin, E., Rocchia, R., Lefevre, I., 2001. The CretaceousPalaeogene (K/P) boundary in the Aïn Settara section (Kalaat Senan, central Tunisia): lithological, micropalaeontological and geochemical evidence. Bulletin de l'Institut Royal des Sciences naturelles de Belgique, Sciences de la Terre 71, 169-190.

Feldmann, R.M., Goolaerts, S., 2005. Palaega rugosa, a new species of fossil isopod (Crustacea) from Maastrichtian rocks of Tunisia. Journal of Paleontology 79 (5), 1031-1035. 
Gale, A.S., 2014. New thoracican cirripedes (Crustacea) from the Jurassic and Cretaceous of the UK. Proceedings of the Geologists' Association 125, 406-418.

Gale, A.S., 2015. Phylogeny of the deep sea cirripede family Scalpellidae based on capitular plate morphology. Zoological Journal of the Linnean Society 176, 1-34.

Gale, A.S., 2019. Thoracican cirripedes (Crustacea) from the Hauterivian (Lower Cretaceous) of Hannover, northern Germany. Proceedings of the Geologists' Association, https://doi.org/10.1016/j.pgeola.2019.03.002.

Gale, A.S., 2020. New thoracican cirripedes (Crustacea) from the Cretaceous of Europe and North Africa. Neues Jahrbuch für Geologie und Paläontologie Abhandlungen xxx, xx$x x$.

Gale, A.S., Schweigert, G., Keupp, H., Röper, M. 2019. A thoracican cirripede (Crustacea) from the Kimmeridgian of Brunn, Germany, and its bearing on the origin of calanticid and scalpellid barnacles. Neues Jahrbuch für Geologie und Paläontologie Abhandlungen 293, 1-17.

Geinitz, H.B., 1843. Die Versteinerungen von Kieslingwald und Nachtrag zur Characteristik des Sächsisch-Böhmischen Kreidegebirges, 23 pp., 6 pls. Dresden/Leipzig.

Godard, G., Viaud, J.-M., 2007. De la Vendée au Sahara - l’aventure tunisienne du géologue Léon Pervinquière (1873-1913). Éditions du Centre Vendéen de Recherches Historiques, La-Roche-sur-Yon, France, 280 pp.

Goolaerts, S., Kennedy, W.J., Dupuis, C., Steurbaut, E., 2004a. Terminal Maastrichtian ammonites from the Cretaceous-Paleogene Global Stratotype Section and Point, EI Kef, Tunisia. Cretaceous Research 25, 313-328.

Goolaerts, S., Dupuis, C., Steurbaut, E., 2004b. Role of palaeo-environment in ammonite distribution: a Late Cretaceous example from Tunisia. In: Servais, T., Blieck, A., 

Palaeontological Association Newsletter 57, 155-156.

527

Goolaerts, S., 2010. Late Cretaceous ammonites from Tunisia: chronology and causes of their extinction and extrapolation to other areas. Aardkundige Mededelingen 21, xii $+1-220$

Hardenbol, J., Caron, M., Amédro, F., Dupuis, C., Robaszynski, F., 1993. The CenomanianTuronian boundary in central Tunisia in the context of a sequence stratigraphic interpretation. Cretaceous Research 14, 449-454.

Hennebert, M., 2012. Hunting for 405-kyr eccentricity cycle phase at the CretaceousPaleogene boundary in the Aïn Settara section (Kalaat Senan, central Tunisia): Carnets de Géologie/Notebooks on Geology, Article 2012/05 (CG2012_A05), 93-116.

Hennebert, M., Dupuis, C., 2003. Proposition d'une échelle chronométrique autour de la limite Crétacé-Paléogène par cyclostratigraphie: coupe de l’Aïn Settara (Kalaat Senan, Tunisie centrale). Geobios 36, 707-718.

Hewaidy, A.A., El-Azabi, M.H., Farouk, S., 2006. Facies associations and sequence stratigraphy of the Upper Cretaceous-Lower Eocene succession in the Farafra Oasis, Western Desert, Egypt, pp. 569-599. International Conference on the Geology of the Arab World GAW8, Cairo University, Giza, Egypt.

Hoek, P.P.C., 1883. Report on the Cirripedia. Report on scientific results from the exploratory voyages of the Challenger, Zoology 8(25), 1-169.

Hoek, P.P.C., 1907. The Cirripedia of the Siboga Expedition. A, Cirripedia Pedunculata. Siboga Expedition 31a, 1-127, 8 pls. 
Jagt, J.W.M., Collins, J.S.H., 1989. Upper Cretaceous cirripedes from NE Belgium. Proceedings of the Geologists' Association 100, 183-192.

Jagt, J. W. M., Verhesen, W., Goolaerts, S., 2016. Notes on Cretaceous cirripedes (Crustacea, Thoracica) from Tunisia - Part 1. A new species of Pachyscalpellum Buckeridge, 1991. In: Sullivan, R. M. and Lucas, S. G. (eds), Fossil Record 5. New Mexico Museum of Natural History and Science Bulletin, 104, 101-106.

Jones, D.S., Hosie, A.M. 2008. A new species of Calantica from Western Australian waters (Thoracica: Scalpellomorpha: Calanticidae). Records of the Western Australian Museum 25, 239-246.

Kočova Veselská, M., Kočí, T., Buckeridge, J.S., 2020. Cirripedia (Crustacea) from hemipelagic deposits of the Bohemian Cretaceous Basin, with remarks on an exceptionally wellpreserved capitulum of Diotascalpellum angustatum (Geinitz, 1843). In: Jagt, J.W.M., Fraaije, R.H.B., Van Bakel, B.W.M., Donovan, S.K., Mellish, C. (Editors), A lifetime amidst fossil crustaceans: a tribute to Joseph S.H. Collins (1927-2019). Neues Jahrbuch für Geologie und Paläontologie Abhandlungen.

Landman, N.H., Goolaerts, S., Jagt, J.W.M., Jagt-Yazykova, E.A., Machalski, M., Yacobucci, M., 2014. Ammonite extinction and nautilid survival at the end of the Cretaceous. Geology 42, 707-710.

Landman, N.H., Goolaerts, S., Jagt, J.W.M., Jagt-Yazykova, E.A., Machalski, M., 2015. Ammonites on the brink of extinction: diversity, abundance, and ecology of the Order Ammonoidea at the Cretaceous-Paleogene (K/Pg) boundary. In: Klug, C., Korn, D., De Baets, K., Kruta, I., Mapes, R.H. (Editors), Ammonoid paleobiology: from macroevolution to paleogeography. Topics in Geobiology 44, 497-553. 
Lehotsky, J., Bujinovsky, A., Lajmi, T.Z., Ben Salem, H., 1978. Carte géologique de la Tunisie au $1 / 50.000^{\mathrm{e}}$. Feuille $\mathrm{n}^{\circ}$ 59: Kalaat Es Senan. Sous direction de la géologie au Ministère des Mines et de l'Industrie, Service Géologique de la Tunisie, Notice «1995» (published in 1998).

Meek, F. B. 1870. A preliminary list of fossils collected by Dr. Hayden in Colorado, New Mexico and California with brief descriptions of new species. Proceedings of the American Philosophical Society 11, 425-431.

Molina, E., Alegret, L., Arenillas, I., Arz, J.A., Gallala, N., Grajales-Nishimura, J.M., MurilloMuñetón, G., Zaghbib-Turki, D., 2009. The Global Boundary Stratotype Section and Point for the base of the Danian Stage (Paleocene, Paleogene, "Tertiary", Cenozoic): auxiliary sections and correlation. Episodes 32(2), 84-95.

Newman, W.A. (1996). Cirripedia; Suborders Thoracica and Acrothoracica. In : Traité de Zoologie, Tome VII, Crustacés, Fascicule 2, 453 - 540. Masson, Paris.

Peron, A., 1893. Exploration scientifique de la Tunisie. Paléontologie. Description des brachiopodes, bryozoaires et autres invertébrés fossiles des terrains crétacés 3, 328405. Paris, Imprimerie nationale.

Pervinquière, L., 1903. Études géologiques de Tunisie centrale. De Rudeval, Paris, 360 pp.

Pervinquière, L., 1907. Études de paléontologie tunisienne. 1. Céphalopodes des terrains secondaires. Carte Géologique de la Tunisie, Direction Générale des Travaux Publics. De Rudeval, Paris, 438 pp.

Pervinquière, L., 1912. Étude de paléontologie tunisienne. 2. Gastropodes et lamellibranches des terrains crétacés. Lamarre, Paris, 352 pp.

Philippi, R.A., 1835. Beschreibung einer neuen Art Pollicipes. Neues Jahrbuch für Geologie, Mineralogie und Paläontologie 1835, 512-515. 
594

595

596

597

598

599

600

601

602

603

604

605

606

607

608

609

610

611

612

613

614

615

616

617

Pilsbry, H.A., 1907. The barnacles (Cirripedia) contained in the collections of the U.S. National Museum. Bulletin of the United States National Museum 60, 1-122, 11 pls.

Pilsbry, H.A., 1916. The sessile barnacles (Cirripedia) contained in the collections of the National Museum; including a monograph of the American species. Bulletin of the United States National Museum 93, xii + 1-366.

Quaas, A., 1902. Beitrag zur Kenntniss der Fauna der obersten Kreidebildungen in der libyschen Wüste (Overwegischichten und Blätterthone). Palaeontographica 30, 150334, pls. 20-33.

Robaszynski, F., Amédro, F., Caron, M., 1993a. La limite Cénomanien-Turonien et la Formation Bahloul dans quelques localités de Tunisie centrale. Cretaceous Research $14(4 / 5), 477-486$.

Robaszynski, F., Amédro, F., Gonzalez-Donoso, J.M., Linares, D., 2007. Les bioévénements de la limite Albien (Vraconnien)-Cénomanien aux marges nord et sud de la Téthys (S.E. de la France et Tunisie centrale). In: Bulot, L.G., Ferry, S., Grosheny, D. (Editors), Relations entre les marges septentrionale et méridionale de la Téthys au Crétacé. Carnets de Géologie/Notebooks on Geology, Brest, Mémoire 2007/02, Résumé 01 (CG2007_M02/01).

Robaszynski, F., Caron, M., Amédro, F., Dupuis, C., Hardenbol, J., Gonzalez Donoso, J.M., Linares, D., Gartner, S., 1993b. Le Cénomanien de la région de Kalaat Senan (Tunisie centrale): litho-biostratigraphie et interprétation séquentielle. Revue de Paléobiologie 12 (2), 351-505.

Robaszynski, F., Caron, M., Dupuis, C., Amédro, F., Gonzalez Donoso, J.M., Linares, D., Hardenbol, J., Gartner, S., Calandra, F., Deloffre, R., 1990. A tentative integrated stratigraphy in the Turonian of central Tunisia: formations, zones, and sequential 

stratigraphy in the Kalaat Senan area. Bulletin des Centres de Recherches Exploratoires Productions Elf-Aquitaine 14 (1), 213-384.

Robaszynski, F., Gonzalez Donoso, J.M., Linares, D., Amédro, F., Caron, M., Dupuis, C., Dhondt, A.V., Gartner, S., 2000. Le Crétacé supérieur de la région de Kalaat Senan, Tunisie centrale. Lithobiostratigraphie intégrée: zones d'ammonites, de foraminifères planctoniques et de nannoplancton de Turonien au Maastrichtien. Bulletin du Centre de Recherches et d'Exploration et Production d'Elf Aquitaine 22, 359-490.

Robaszynski, F., Hardenbol, J., Caron, M., Amédro, F., Dupuis, C., Gonzalez Donoso, J.M., Linares, D., Gartner, S., 1993c. Sequence stratigraphy in a distal environment: the Cenomanian of the Kalaat Senan region (central Tunisia). Bulletin des Centres de Recherches Exploration-Production Elf-Aquitaine 17 (2), 395-433.

Roemer, F.A., 1841. Die Versteinerungen des norddeutschen Kreidegebirges 2, 49-145, pls 8-16. Hahn'sche Hofbuchhandlung, Hannover.

Rohlfs, G., 1875. Expedition zur Erforschung der libyschen Wüste unten den Auspicien Sr. Hoheit des Chedive von Aegypten Ismail-Pascha im Winter 1873-1874 ausgefürht. Erster Band: Reisebericht. Theodor Fischer Verlag, Cassel.

Russell, L. S. 1967. A pedunculate cirripede from Upper Cretaceous rocks of Saskatchewan. Journal of Paleontology 41, 1544-1547.

Seguenza, G., 1876. Ricerche palaeontologiche intorno al Cirripedi Terziarii della provincia di Messina. Parte II. Terza famiglia Lepadi Darwin. Atti dell'Accademica Pontoniana 10, $1-112$.

Sowerby, J. de C., 1829. The Mineral Conchology of Great Britain 6, 221-222, pl. 606; 7, pls. 647,648 . The author, London. 
642 Sowerby, J. de C., 1836. Descriptive notes respecting shells figured in plates 11-22 (pp. 335-

643

644

645

646

647

648

649

650

651

652

653

654

655

656

657

658

659

660

661

662

663 348). Appendix A to Fitton, W.H. Observations on some of the strata between the Chalk and the Oxford Oolite in the south-east of England. Transactions of the Geological Society of London (2)4, 103-389, pls 11-23.

Steurbaut, E., Dupuis, C., Arenillas, I., Molina, E., Matmati, M.F., 2000. The Kalaat Senan section in central Tunisia: a potential reference section for the Danian/Selandian boundary. GFF 122, 158-160.

Thomas, P., 1909. Essai d'une description géologique de Tunisie d'après les travaux des membres de la mission de l'exploration scientifique de 1884 à 1891 et ceux parus depuis. Deuxième partie. Stratigraphie des terrains paléozoïques et mésozoïques, pp. 223-728. Paris, Imprimerie nationale (misdated 1908).

Wanner, J., 1902. Die Fauna der obersten weissen Kreide der libyschen Wüste. Palaeontographica 30, 91-151, pls 13-19.

Withers, T.H., 1911. Some cirripedes from the Chalk of Salisbury, Wilts. Geological Magazine (5) $8,21-31$.

Withers, T.H., 1922. The morphology of some Cretaceous cirripedes. The Annals and Magazine of Natural History, 9(9), 368-379, pl. 5.

Withers, T.H., 1926. A new cirripede from the Upper Cretaceous of Western Australia. Journal of the Royal Society of Western Australia 12, 101-104.

Withers, T.H., 1928. British Museum (Natural History). Catalogue of fossil Cirripedia in the Department of Geology. Vol. 1. Triassic and Jurassic, xii + 1-154, 12 pls. Trustees of the British Museum (Natural History), London. 
Withers, T.H., 1935. British Museum (Natural History). Catalogue of fossil Cirripedia in the

665 Department of Geology. Vol. 2. Cretaceous, xiii $+1-534,50$ pls. Trustees of the

666 British Museum (Natural History), London.

667 Woodward, H., 1906. Cirripedes from the Trimmingham Chalk and other localities in 668 Norfolk. Geological Magazine (5)3, 337-353.

669

670

671 Figures

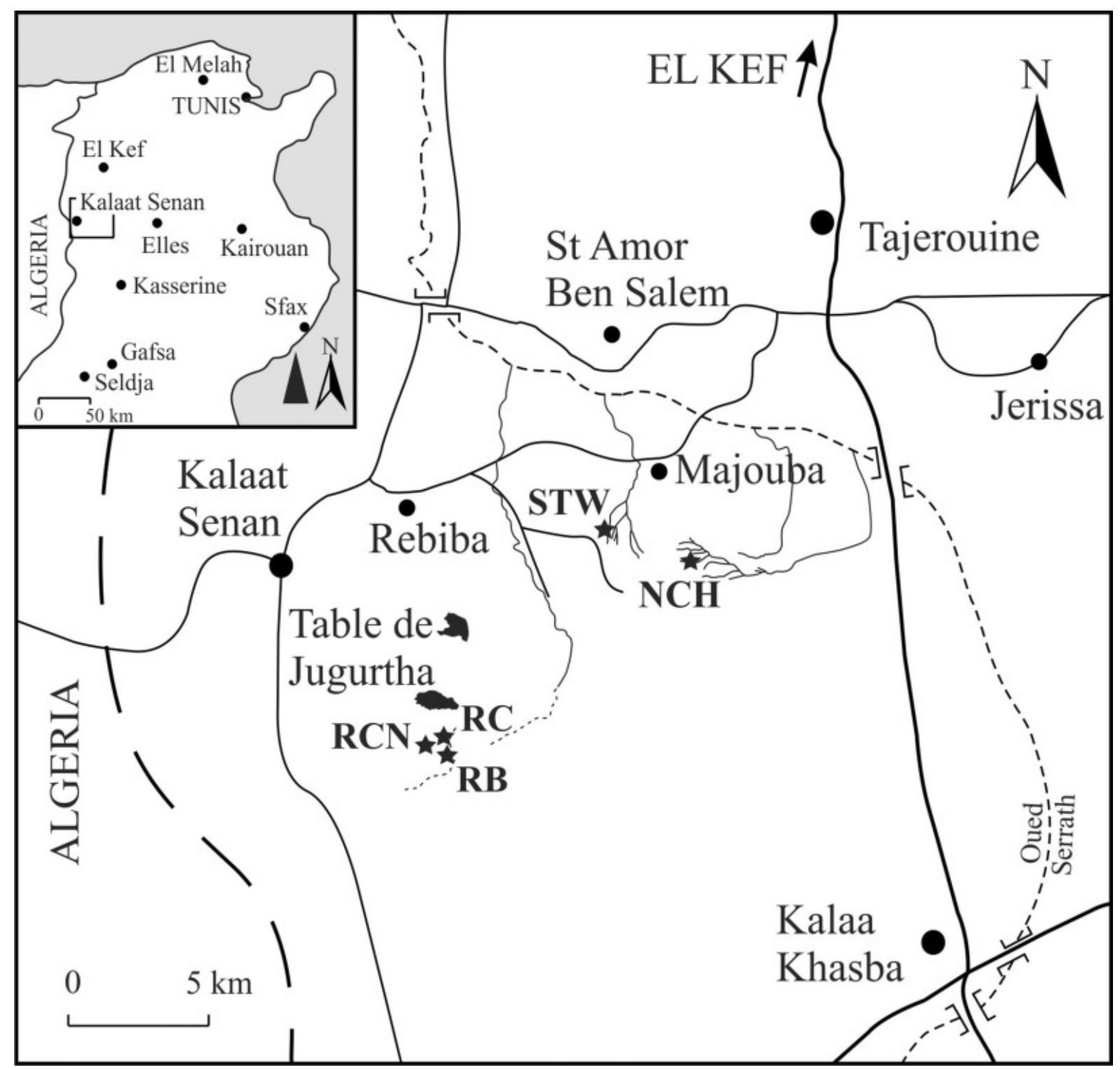


673 Fig. 1. Map of the Kalaat Senan area (inset showing its position within Tunisia, close to the 674 border with Algeria), with sections where cirripedes were found indicated as follows: STW 675 Aïn Settara section; RCN - Oued Raïne RCN section, 500 m west of RC and RB sections; RC 676 Oued Raïne RC section; RB - Oued Raïne RB section; NCH - Ncham section (for details see 677 Goolaerts, 2010).

678 


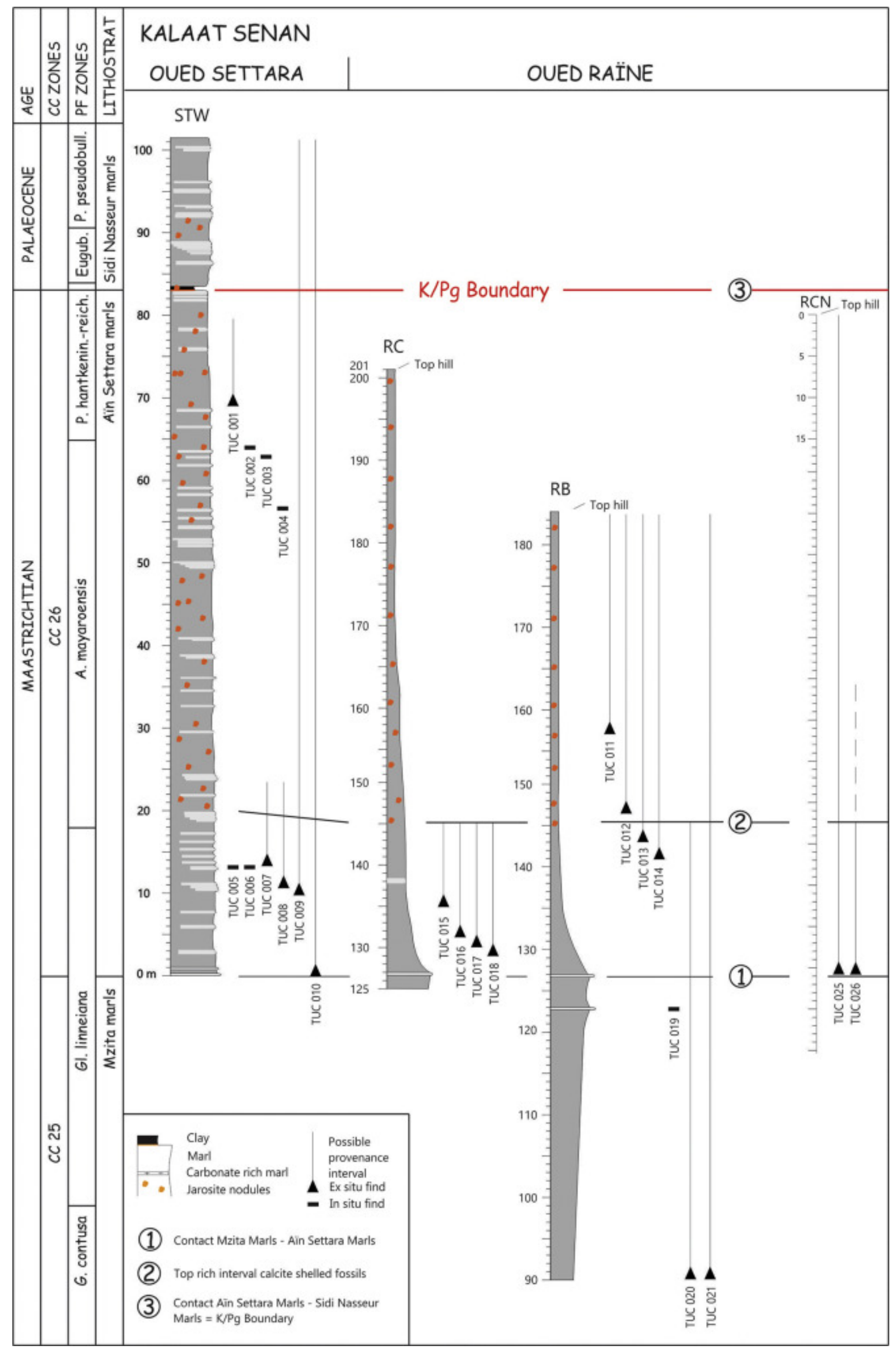


681 of sample provenance.

682

683

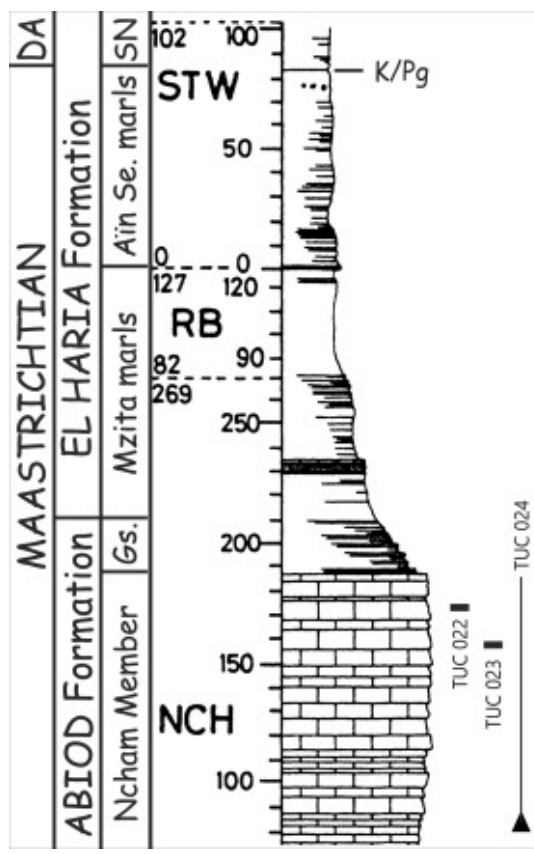

\begin{tabular}{|c|c|c|c|c|}
\hline \multicolumn{2}{|c|}{ PLANKT FORAM ZONES } & \multirow{4}{*}{$\begin{array}{c}\text { CC ZONES } \\
\text { CC } 26\end{array}$} & \multirow{2}{*}{$\begin{array}{c}\text { AMMONITE ZONES } \\
\text { Indo. pavana AZ }\end{array}$} & CIRRIPEDE SPECIES \\
\hline \multirow{4}{*}{ 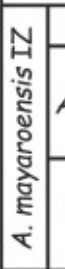 } & PI. reicheli PR sz & & & \multirow{10}{*}{ 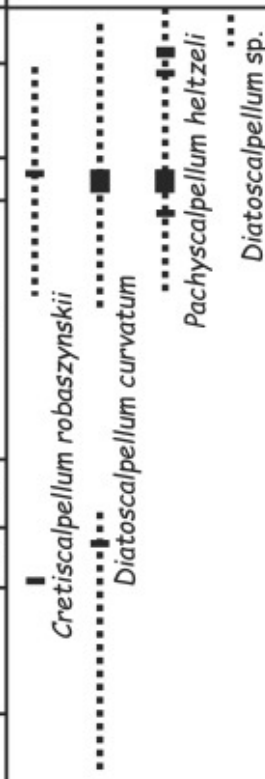 } \\
\hline & A. mayaroensis PR sz & & Hoplo. n.sp. AZ & \\
\hline & & & Disco. conradi IZ & \\
\hline & & CC 25 & \multirow{3}{*}{$\begin{array}{l}\text { P. (Neodesmoceras) }) \\
\text { n.sp. Event }\end{array}$} & \\
\hline \multirow{6}{*}{ 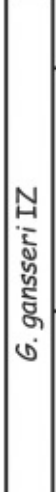 } & C. contusa I sz & \multirow{3}{*}{ CC 24} & & \\
\hline & \multirow{3}{*}{ Glo. stuarti PR sz } & & & \\
\hline & & & P. (P.) neubergicus PRZ & \\
\hline & & \multirow{3}{*}{ cC 23} & N. (N.) alternatum RZ & \\
\hline & \multirow{2}{*}{ Ar. kefiana TR sz } & & Nostoceras? sp. IZ & \\
\hline & & & $N .(N$.$) magdadiae R Z$ & \\
\hline
\end{tabular}

684 Fig. 3. Composite stratigraphical log of the Maastrichtian of the Kalaat Senan area, with

685 positioning of the three samples from the lower Maastrichtian Ncham Member (Abiod

686 Formation) of the NCH section, calcareous nanoplankton zones (after Gartner in

687 Robaszynski et al., 2000), planktonic foraminifer zones (after Robaszynski in Robaszynski et

688

al., 2000), ammonite zones and events (after Goolaerts, 2010) and range chart of cirripede

689

species documented. Abbreviations are as follows: DA - Danian; Gs. - Gouss Member; Aïn

690

Se. marls - Aïn Settara marls; SN - Sidi Nasseur marls; IZ - Interval Zone; PR sz - Partial

691

Range subzone; TR sz - Total Range subzone; I sz - Interval subzone; A. - Abathomphalus; G.

692

- Ganserina; Pl. - Plummerita; Gl. - Globotruncana; C. - Contusatruncana; Glo. -

693

Globotruncanita; Ar. - Archaeoglobotruncana; Indo. - Indoscaphites; Hoplo. -

694 Hoploscaphites; Disco. - Discocaphites; P. - Pachydiscus; N. - Nostoceras. 


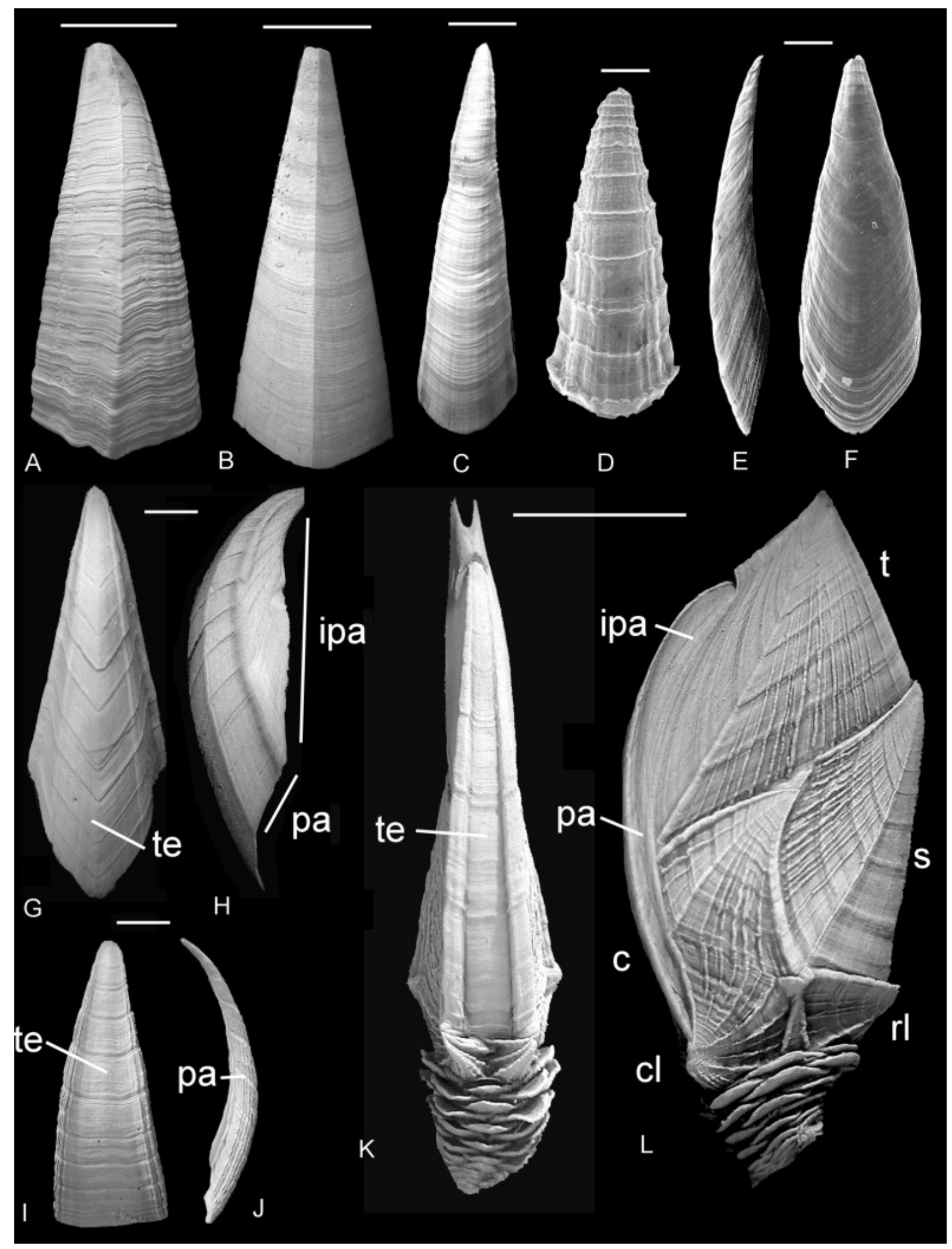

697 Fig. 4. Nomenclature of scalpellomorph barnacles and comparative morphology of carinae.

698 A-J, morphology of carinae, to show variation between families: Calanticidae (A, C),

699 Cretiscalpellidae (B), Zeugmatolepadidae (D-F) and Scalpellidae (G-L). A. external view of 
calanticid Scillaelepas carinata (Phillipi, 1835) (A.S. Gale Collection). B. external view of

701 cretiscalpellid Cretiscalpellum unguis (J. de C. Sowerby, 1836), the original (NHMUK IC 1346)

702 of Gale et al. (2019, fig. 6B). C. external view of Calantica sp. (A.S. Gale Collection). D.

703 external view of Etcheslepas fragilis (Withers, 1928), the original (NHMUK IC 1099) of Gale

704 (2014, fig. 6k). E, F. lateral and external views of Martillepas hollisi (Withers, 1928), the

705 original (NHMUK IC 1123) of Gale (2014, fig. 8p, q). G, H. Regioscalpellum maximum forma

706 sulcatum (J. de C. Sowerby, 1829), in external and lateral views, respectively; the original

707 (NHMUK I 13663) of Withers (1935, pl. 32, fig. 6). I, J. Arcoscalpellum michelottianum

708 (Seguenza, 1876), in external and lateral aspects, respectively; note the absence of

709 intraparietes (A.S. Gale Collection). K, L. Amigdaloscalpellum sp., capitulum in dorsal and

710 lateral views, respectively; the original of Gale (2015, fig. 1A, B). Provenance: A. lower

711 Pleistocene, Scoppo, Sicily (Italy). B. upper Albian, Gault Clay, Naccolt, Kent, UK. C. present

712 day, Australia. D-F. Kimmeridge Clay, Pavlovia pallasioides ammonite Zone, Tithonian,

713 Portland, Dorset (UK). G, H. upper Campanian, Belemnitella mucronata belemnite Zone,

714 near Norwich, Norfolk (UK). I, J. lower Pleistocene, abyssal, off Rodrigues Ridge, Mascarene

715 Plateau, Indian Ocean. K, L, present day, off Rodrigues Ridge, Mascarene Plateau, Indian

716 Ocean. Abbreviations: c, carina; cl, carinolatus; ipa, intraparietes; pa, parietes; rl,

717 rostrolatus; s, scutum; t, tergum; te, tectum. Scale bars equal $5 \mathrm{~mm}(\mathrm{~A}-\mathrm{C}, \mathrm{G}-\mathrm{L})$ and $0.5 \mathrm{~mm}$ 718 (D-F). 


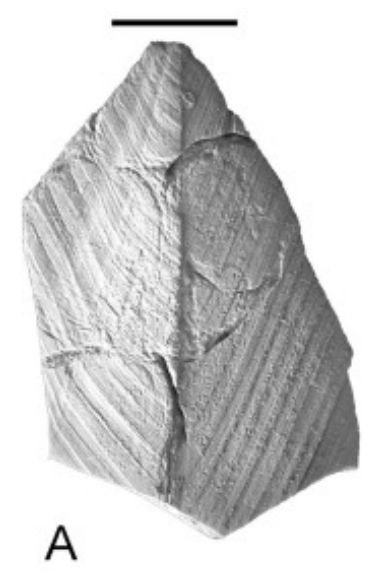

B
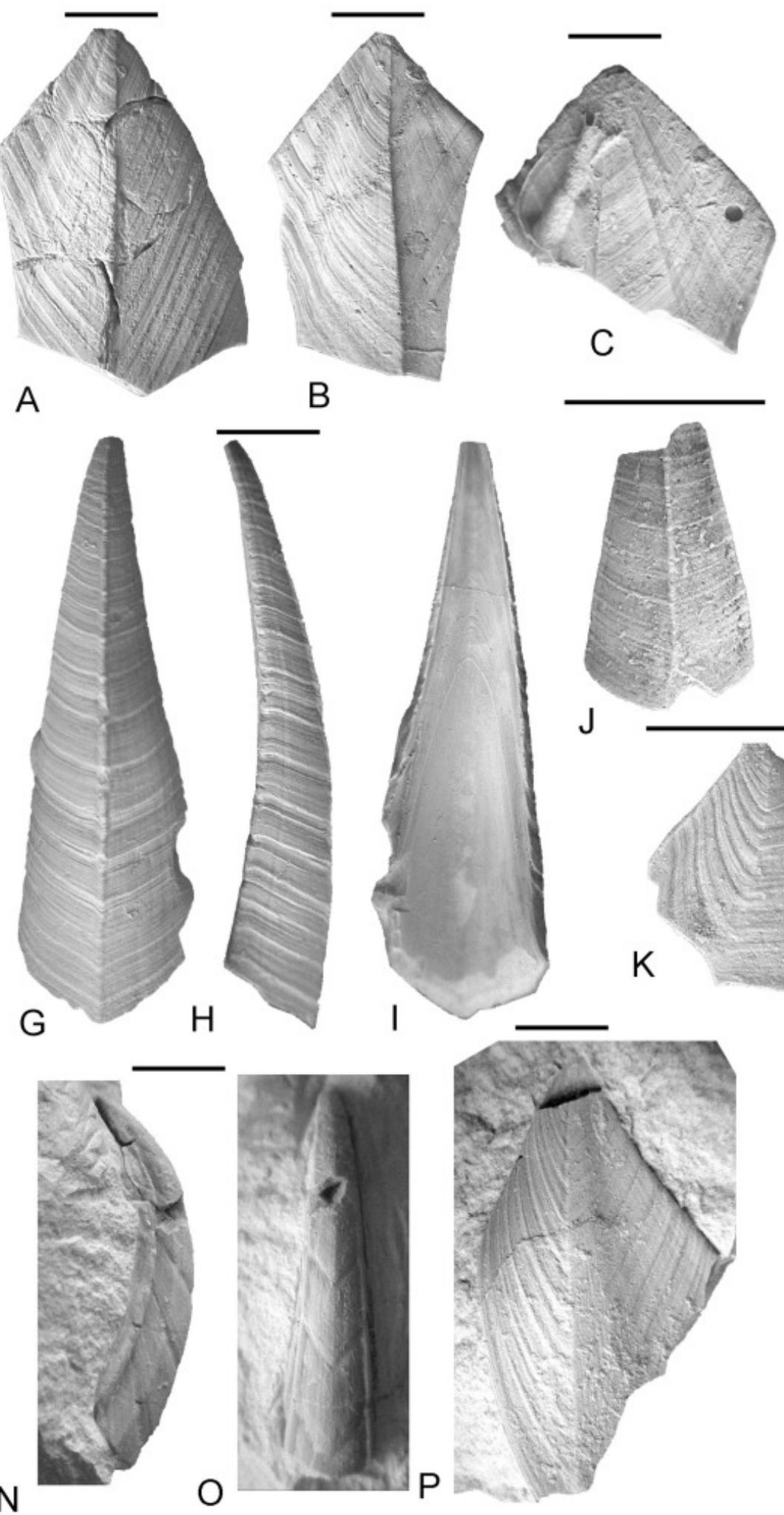

721 Fig. 5. Cretiscalpellid (A-C, G-J) and scalpellid (D-F, K-Q) cirripedes from the Maastrichtian

722 of Kalaat Senan, Tunisia. A-C, G-J. Cretiscalpellum robaszynskii sp. nov. A-C. Paratype terga, 

carina (holotype), NHMM 2019 026, in external, lateral and internal views, respectively,. J,

725 carina (paratype), NHMM 2019 027, in external view. K-Q, Diotascalpellum curvatum

726 (Wanner, 1902). K, L, M, Q, three scuta, NHMM 2019 033, NHMM 2019034 and NHMM

7272019035 respectively, in external views (K, M, Q) and internal aspect (L). N, O. Carina,

728 NHMM 2019 036, in lateral and dorsal views, respectively. P. Tergum, NHMM 2019 032, in

729 external view,. D-F. Diotascalpellum sp., carina, NHMM 2019 037, in internal, external and 730 lateral views, respectively,. Scale bars equal $5 \mathrm{~mm}$.

731 

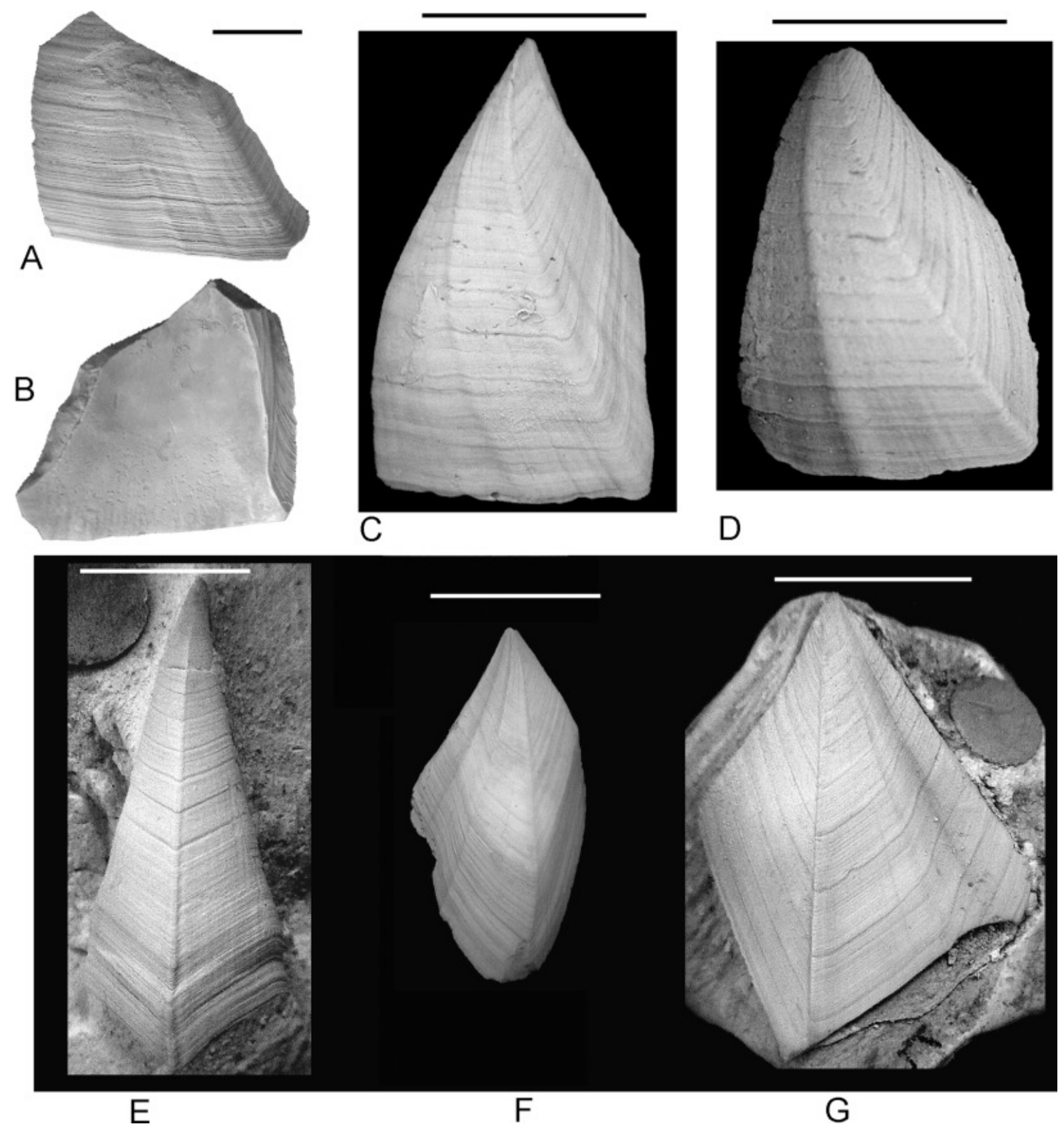

Fig. 6. Cretiscalpellid cirripedes. A, B. Cretiscalpellum robaszynskii sp. nov., paratype partial

734 scutum, NHMM 2019 031, in external and internal views, respectively. C, F. Cretiscalpellum paucistriatum (Woodward, 1906), scutum in external view (C), the original of Woodward

736 (1906, fig. 31) and Withers (1935, pl. 18, fig. 8) (NHMUK I. 30156) and tergum (F, lectotype;

737 the original of Woodward (1906, fig. 32) and Withers (1935, pl. 18, fig. 9)) (NHMUK I.

738 30157). D, Witherscalpellum matrioni (Gale, 2019), scutum in external view; the original of

739 Gale (2019, fig. 7D), B. Matrion Collection, University of Dijon, France. E, G. Cretiscalpellum 
740 glabrum (Roemer, 1841), carina in external view (E, NHMUK I. 13656) and tergum in

741 external view (G., NHMUK I. 13652). Provenance: A, B. Maastrichtian, Kalaat Senan, Tunisia;

742 C, F. lower Maastrichtian, Trimingham, Norfolk, United Kingdom. E, G. upper Campanian,

743 Belemnitella mucronata belemnite Zone, near Norwich, Norfolk, United Kingdom. Scale bars

744 equal $5 \mathrm{~mm}(\mathrm{~A}, \mathrm{~B})$ and $10 \mathrm{~mm}(\mathrm{C}-\mathrm{F})$.

745

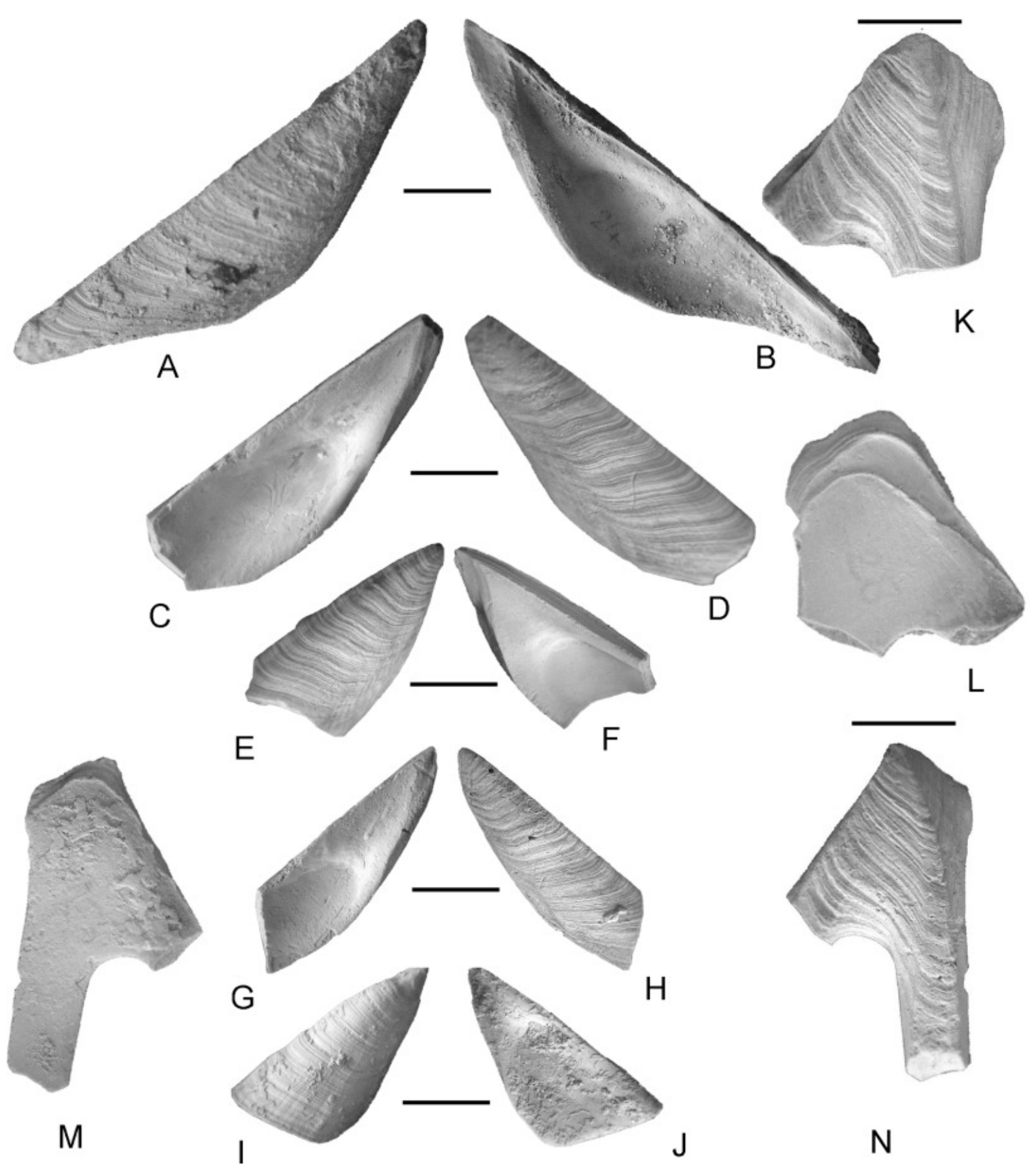


Fig. 7. Pachyscalpellum heltzeli Jagt, Verhesen and Goolaerts, 2016 from the Maastrichtian

748 of Kalaat Senan, Tunisia. A-J. Scuta to demonstrate ontogenetic changes. A, B. Largest

749 specimen (NHMM 2015 020q), showing extreme elongation of the rostral region, in external

750 and internal views, respectively. C, D. NHMM 2015 020n. E, F. NHMM 2015 020o. G, H.

751 Internal and external views, the original (NHMM 2015 020p) of Jagt et al. (2016, fig. 5H-J). I,

752 J. Smallest specimen (NHMM 2015 020b), lacking rostral extension. K-N. Partial terga, in

753 external (K, N) and internal (L, M) views; K, L. The original (NHMM 2015 020q) of Jagt et al.

754 (2016, fig. 3K, L). M, N. The original (NHMM 2015 020w, holotype) of Jagt et al. (2016, fig.

$7553 G)$. Scale bars equal $5 \mathrm{~mm}$.

756 


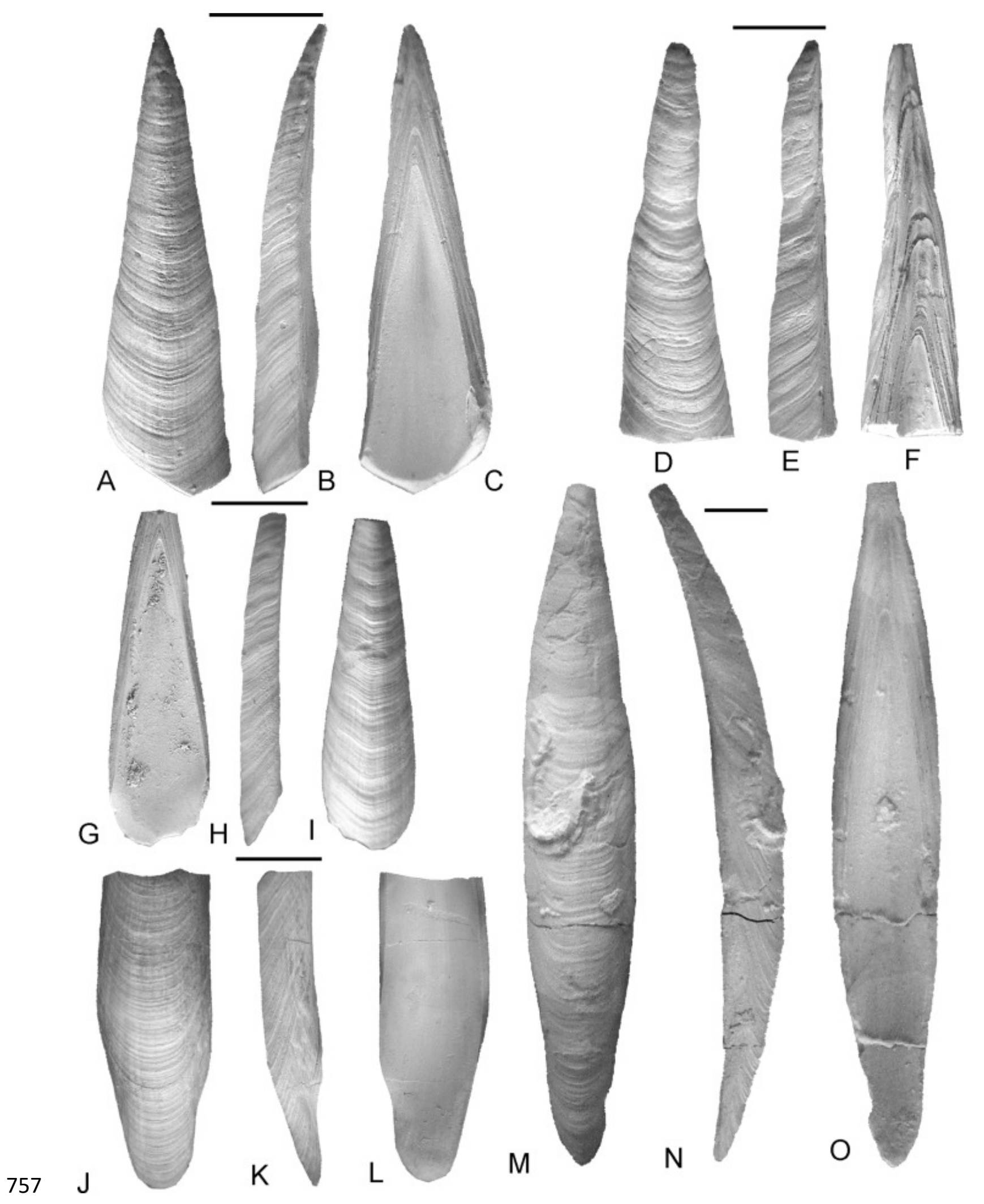

758 Fig. 8. Pachyscalpellum heltzeli Jagt, Verhesen and Goolaerts, 2016 from the Maastrichtian

759 of Kalaat Senan, Tunisia. Carinae, to show variation of form. A-C. NHMM 2015 20i, in

760 external, lateral and internal views, respectively. D-F. NHMM 2015 020h, with change in 
761 growth direction in external, lateral and internal views, respectively. G-I. NHMM 2015 020j,

762 showing weak radial sculpture in external, lateral and internal views, respectively. J-L,

763 NHMM 2015 020t, basal portion of carina, displaying narrowing towards the basal margin,

764 in external, lateral and internal views, respectively (the original of Jagt et al., 2016, fig. 5A-

765 C). M-O, NHMM 2015 020u, very large carina, displaying narrowing towards basal margin

766 (the original of Jagt et al., 2016, fig. 5). Scale bars equal $5 \mathrm{~mm}$.

767 


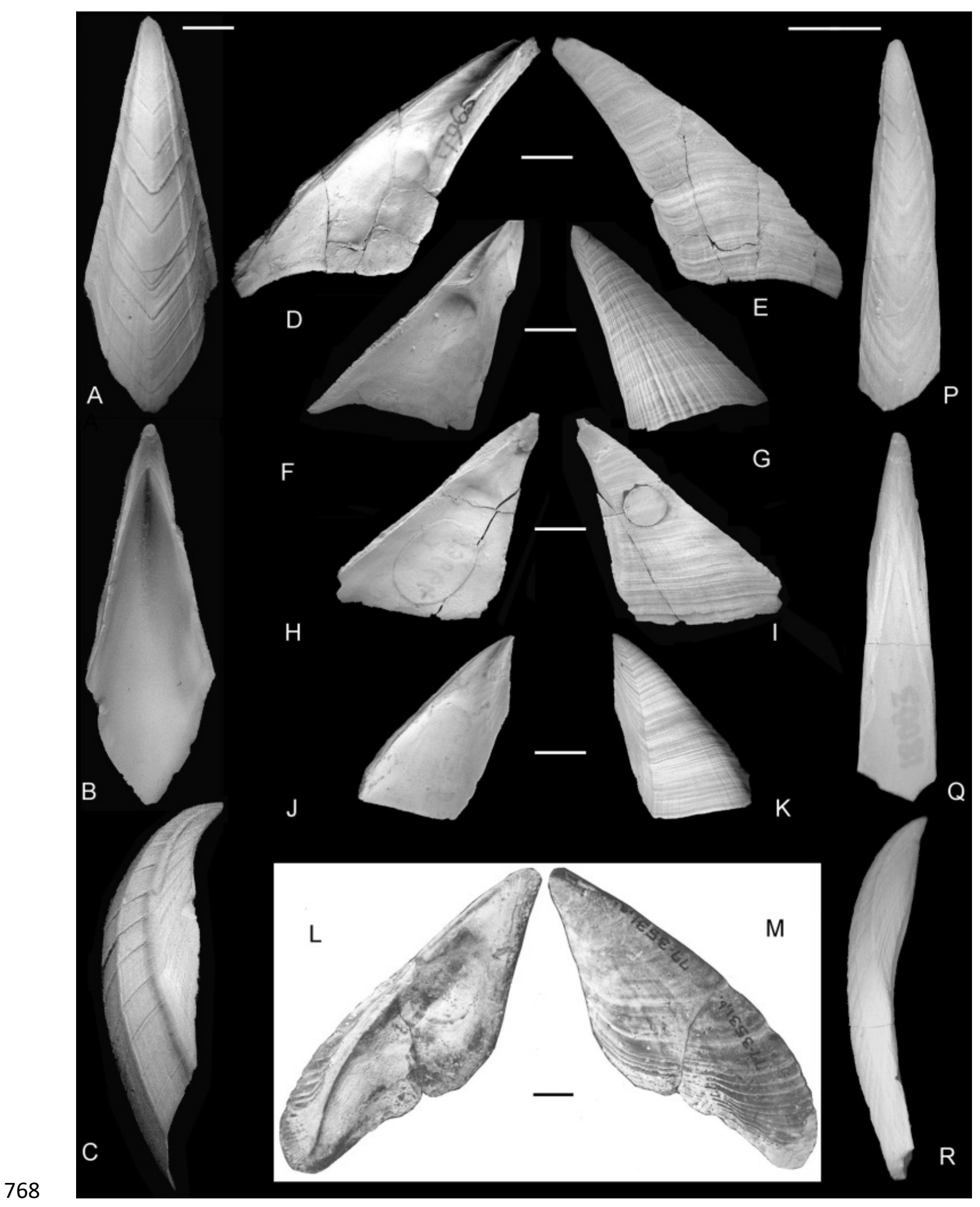

769 Fig. 9. Scalpellid and pollicipid valves to show convergent evolution with Pachyscalpellum.

770 A-C. Regioscalpellum maximum forma sulcatum (J. de C. Sowerby, 1829), carina, in external,

771 internal and lateral views, respectively (the original of Withers, 1935, pl. 32, fig. 6; NHMUK I 
13663). D-K, P-R, Regioscalpellum maximum var. cylindricum (Darwin, 1851). D-K, growth series of scuta, to show progressive elongation of rostral portion of valve with size, in parallel with Pachyscalpellum heltzeli (compare with Fig. 7). D, E. very large scutum, in internal and external views, respectively (NHMUK In.63533). F, G. scutum in internal and external views, respectively (NHMUK In. 26347). H, I, scutum, in internal and external views, respectively (NHMUK I.13664). J, K, small scutum, similar to those of Regioscalpellum maximum (compare with Withers, 1935 , pls 30,31 ), the original of Withers (1935, pl. 30, fig. 4; (NHMUK I. 3668). P-R. carina, in external, internal and lateral views, respectively, to show apical thickening (NHMUK In. 63520). L, M. Pollicipes aboriginalis Buckeridge, 1983, scutum (holotype), refigured after Buckeridge (1983, pl. 3a, b; WAM 77.3531); note similarities to figs D and E and Fig. 7A, B. Provenance: A-C, F-K. upper Campanian, Belemnitella mucronata belemnite Zone, near Norwich, Norfolk, United Kingdom. D, E. upper Campanian, Belemnitella mucronata belemnite Zone, upper Weybourne or basal Beeston Chalk, Attoe's Pit, Norwich, Norfolk, United Kingdom. P-R. upper Campanian, Belemnitella mucronata belemnite Zone, Earlham Limeworks, Norwich, Norfolk, United Kingdom. L, M. Gingin Chalk, upper Santonian, Perth Basin, Dundaragan, Western Australia. Scale bars equal $5 \mathrm{~mm}$.

(1)


795 Table 1. Sample numbers, section and level of origin, stratigraphic level and CC zone (from

796 Robaszynski et al., 2000 with data from S. Gartner), taxonomy, specimen number, status

797 and figurations in Jagt et al (2016) and this paper.

798 


\begin{tabular}{|c|c|c|c|c|c|c|c|c|c|c|c|}
\hline Sample No & Section & Level & Situ & Lithostratigraphy & CC zone & Taxonomy & NHMM numbers & Plate type & Status & Jagt et al 2016 & This paper \\
\hline TUC 001 & STW & STW 69 & ex situ & Aïn Settara or Sidi Nasseur Marls & $\mathrm{CC} 26$ & Diatoscalpellum $\mathrm{sp}$. & NHMM 2019037 & carina & Figured & & Fig 5 D, E, F \\
\hline TUC 002 & STW & STW 64 & in situ & Aïn Settara Marls & $\mathrm{CC} 26$ & Pachyscalpellum heltzeli & NHMM 2015 020a & carina & & & \\
\hline TUC 003 & STW & STW 62,5 & in situ & Aïn Settara Marls & $\mathrm{CC} 26$ & Pachyscalpellum heltzeli & NHMM 2015 020b & right scutum & Figured & & Fig $7 \mathrm{I}, \mathrm{J}$ \\
\hline TUC 004 & STW & STW 56,5 & in situ & Aïn Settara Marls & $\mathrm{CC} 26$ & Pachyscalpellum heltzeli & NHMM 2015 020c & carina & & & \\
\hline TUC 005 & STW & STW 13 & in situ & Aïn Settara Marls & $\mathrm{CC} 26$ & Cretiscalpellum robaszynskii & & fragmentary tergum & & & \\
\hline TUC 006 & STW & STW 13 & in situ & Aïn Settara Marls & $\mathrm{CC} 26$ & Cretiscalpellum robaszynskii & NHMM 2019027 & carina & Paratype & & Fig $5 \mathrm{~J}$ \\
\hline TUC 007 & STW & STW 13,5 & ex situ & Aïn Settara Marls & $\mathrm{CC} 26$ & Pachyscalpellum heltzeli & NHMM 2015 020d & carina & & & \\
\hline TUC 007 & STW & STW 13,5 & ex situ & Aïn Settara Marls & $\mathrm{CC} 26$ & Pachyscalpellum heltzeli & NHMM 2015 020e & carina & & & \\
\hline TUC 007 & STW & STW 13,5 & ex situ & Aïn Settara Marls & $\mathrm{CC} 26$ & Pachyscalpellum heltzeli & NHMM 2015 020f & right scutum & & & \\
\hline TUC 008 & STW & STW 10,5 & ex situ & Aïn Settara Marls & $\mathrm{CC} 26$ & Pachyscalpellum heltzeli & NHMM $2015020 \mathrm{~g}$ & carina & & & \\
\hline TUC 009 & STW & STW 10 & ex situ & Aïn Settara Marls & $\mathrm{CC} 26$ & Pachyscalpellum heltzeli & NHMM 2015 020h & carina & Figured & & Fig 8 D, E, F \\
\hline $\begin{array}{l}\text { TUC } 010 \\
\text { TUC } 010 \\
\end{array}$ & $\begin{array}{l}\text { STW } \\
\text { STW }\end{array}$ & $\begin{array}{l}\text { STW } 0 \\
\text { STW } 0 \\
\end{array}$ & $\begin{array}{l}\text { ex situ } \\
\text { ex situ }\end{array}$ & $\begin{array}{l}\text { Aïn Settara Marls } \\
\text { Aïn Settara Marls } \\
\end{array}$ & $\begin{array}{l}\mathrm{CC} 26 \\
\mathrm{CC} 26 \\
\end{array}$ & $\begin{array}{l}\text { Pachyscalpellum heltzeli } \\
\text { Cretiscalpellum robaszynskii }\end{array}$ & NHMM 2015 020i & $\begin{array}{l}\text { carina } \\
\text { fragmentary tergum }\end{array}$ & Figured & & Fig $8 \mathrm{~A}, \mathrm{~B}, \mathrm{C}$ \\
\hline TUC 011 & $\mathrm{RB}$ & RB 157 & ex situ & Aïn Settara Marls & $\mathrm{CC} 26$ & Pachyscalpellum heltzeli & NHMM 2015 020j & carina & Figured & & Fig $8 \mathrm{G}, \mathrm{H}, \mathrm{I}$ \\
\hline TUC 012 & $\mathrm{RB}$ & RB 146,5 & ex situ & Aïn Settara Marls & $\mathrm{CC} 26$ & Pachyscalpellum heltzeli & NHMM 2015 020k & carina & Figured & Fig $3 \mathrm{M}-\mathrm{O}$ & \\
\hline $\begin{array}{l}\text { TUC } 013 \\
\text { TUC } 013 \\
\text { TUC } 013 \\
\end{array}$ & $\begin{array}{l}\mathrm{RB} \\
\mathrm{RB}\end{array}$ & $\begin{array}{l}\text { RB } 143 \\
\text { RB } 143 \\
\text { RB } 143 \\
\end{array}$ & $\begin{array}{l}\text { ex situ } \\
\text { ex situ } \\
\text { ex situ } \\
\end{array}$ & \begin{tabular}{|l} 
Aïn Settara Marls \\
Aïn Settara Marls \\
Aïn Settara Marls \\
\end{tabular} & $\begin{array}{l}\mathrm{CC} 26 \\
\mathrm{CC} 26 \\
\mathrm{CC} 26 \\
\end{array}$ & $\begin{array}{l}\text { Pachyscalpellum heltzeli } \\
\text { Pachyscalpellum heltzeli } \\
\text { Pachyscalpellum heltzeli }\end{array}$ & $\begin{array}{l}\text { NHMM } 20150201 \\
\text { NHMM } 2015 \\
\text { 020m } \\
\text { NHMM } 2015020 \mathrm{n} \\
\end{array}$ & \begin{tabular}{|l} 
carina \\
carina \\
left scutum \\
\end{tabular} & Figured & & Fig $7 \mathrm{C}, \mathrm{D}$ \\
\hline TUC 014 & $\mathrm{RB}$ & RB 141 & ex situ & Aïn Settara Marls & $\mathrm{CC} 26$ & Pachyscalpellum heltzeli & NHMM 2015 020o & right scutum & Figured & Fig 3 D-F & Fig 7 E, F \\
\hline TUC 014 & $\mathrm{RB}$ & RB 141 & ex situ & Aïn Settara Marls & $\mathrm{CC} 26$ & Pachyscalpellum heltzeli & NHMM 2015 020p & left scutum & Figured & Fig 3 H-J & Fig $7 \mathrm{G}, \mathrm{H}$ \\
\hline TUC 014 & $\mathrm{RB}$ & RB 141 & ex situ & Aïn Settara Marls & $\mathrm{CC} 26$ & Cretiscalpellum robaszynskii & NHMM 2019028 & tergum & Figured & & Fig $5 \mathrm{~A}$ \\
\hline TUC 014 & $\mathrm{RB}$ & RB 141 & ex situ & Aïn Settara Marls & $\mathrm{CC} 26$ & Diatoscalpellum curvatum & NHMM 2019035 & scutum & Figured & & Fig 5 Q \\
\hline TUC 014 & $\mathrm{RB}$ & RB 141 & ex situ & Aïn Settara Marls & $\mathrm{CC} 26$ & Pachyscalpellum heltzeli & & carina & & & \\
\hline TUC 015 & $\mathrm{RC}$ & RC 135 & ex situ & Aïn Settara Marls & $\mathrm{CC} 26$ & Pachyscalpellum heltzeli & NHMM 2015 020q & scutum & Paratype & Fig $3 \mathrm{~K}-\mathrm{L}$ & Fig 7 A, B \\
\hline TUC 015 & $\mathrm{RC}$ & RC 135 & ex situ & Aïn Settara Marls & $\mathrm{CC} 26$ & Pachyscalpellum heltzeli & NHMM 2015 020r & tergum & Figured & & Fig $7 \mathrm{~K}, \mathrm{~L}$ \\
\hline TUC 015 & $\mathrm{RC}$ & RC 135 & ex situ & Aïn Settara Marls & $\mathrm{CC} 26$ & Diatoscalpellum curvatum & NHMM 2019034 & right scutum & Figured & & Fig $5 \mathrm{~L}, \mathrm{M}$ \\
\hline TUC 015 & $\mathrm{RC}$ & RC 135 & ex situ & Aïn Settara Marls & $\mathrm{CC} 26$ & Cretiscalpellum robaszynskii & & fragmentary scutum & & & \\
\hline TUC 015 & $\mathrm{RC}$ & RC 135 & ex situ & Aïn Settara Marls & $\mathrm{CC} 26$ & Cretiscalpellum robaszynskii & & fragmentary tergum & & & \\
\hline TUC 016 & $\mathrm{RC}$ & RC 131 & ex situ & Aïn Settara Marls & $\mathrm{CC} 26$ & Pachyscalpellum heltzeli & NHMM 2015 020s & right scutum & & & \\
\hline TUC 017 & $\mathrm{RC}$ & RC 130 & ex situ & Aïn Settara Marls & $\mathrm{CC} 26$ & Cretiscalpellum robaszynskii & NHMM 2019026 & carina & Holotype & & Fig 5 G, H, I \\
\hline TUC 018 & $\mathrm{RC}$ & RC 129 & ex situ & Aïn Settara Marls & $\mathrm{CC} 26$ & Pachyscalpellum heltzeli & NHMM $2015020 \mathrm{t}$ & carina & Figured & Fig 3A-C & Fig $8 \mathrm{~J}, \mathrm{~K}, \mathrm{~L}$ \\
\hline TUC 019 & $\mathrm{RB}$ & RB 123 & in situ & Mzita Marls & $\mathrm{CC} 25$ & Pachyscalpellum heltzeli & NHMM $2015020 u$ & carina & Figured & Fig 4 & Fig $8 \mathrm{M}, \mathrm{N}, \mathrm{O}$ \\
\hline $\begin{array}{l}\text { TUC } 020 \\
\text { TUC } 020\end{array}$ & $\begin{array}{l}\mathrm{RB} \\
\mathrm{RB}\end{array}$ & $\begin{array}{l}\text { RB } 90 \\
\text { RB } 90\end{array}$ & $\begin{array}{l}\text { ex situ } \\
\text { ex situ }\end{array}$ & $\begin{array}{l}\text { Mzita Marls } \\
\text { Mzita Marls }\end{array}$ & $\begin{array}{l}\mathrm{CC} 25 \\
\mathrm{CC} 25\end{array}$ & $\begin{array}{l}\text { Pachyscalpellum heltzeli } \\
\text { Cretiscalpellum robaszynskii }\end{array}$ & $\begin{array}{l}\text { NHMM } 2015 \text { 020v } \\
\text { NHMM } 2019031\end{array}$ & $\begin{array}{l}\text { carina } \\
\text { scutum }\end{array}$ & Paratype & & Fig 6 A, B \\
\hline
\end{tabular}




\begin{tabular}{|c|c|c|c|c|c|c|c|c|c|c|c|}
\hline TUC 021 & RB & RB 121 & ex situ & Mzita Marls or Aïn Settara Marls & CC25 or 26 & Cretiscalpellum robaszynskii & NHMM 2019030 & tergum & Paratype & & Fig $5 \mathrm{C}$ \\
\hline TUC 022 & $\mathrm{NCH}$ & $\mathrm{NCH} 170$ & in situ & Ncham Member, Abiod Formation & $\mathrm{CC} 23$ & Diatoscalpellum curvatum & NHMM 2019036 & carina & Figured & & Fig $5 \mathrm{~N}, \mathrm{O}$ \\
\hline $\begin{array}{l}\text { TUC } 023 \\
\text { TUC } 023\end{array}$ & $\begin{array}{l}\mathrm{NCH} \\
\mathrm{NCH}\end{array}$ & $\begin{array}{l}\text { NCH } 159 \\
\text { NCH } 159\end{array}$ & $\begin{array}{l}\text { in situ } \\
\text { in situ }\end{array}$ & $\begin{array}{l}\text { Ncham Member, Abiod Formation } \\
\text { Ncham Member, Abiod Formation }\end{array}$ & $\begin{array}{l}\mathrm{CC} 23 \\
\mathrm{CC} 23\end{array}$ & $\begin{array}{l}\text { Cretiscalpellum robaszynskii } \\
\text { Cretiscalpellum robaszynskii }\end{array}$ & & $\begin{array}{l}\text { fragment } \\
\text { fragment }\end{array}$ & & & \\
\hline TUC 024 & $\mathrm{NCH}$ & $\mathrm{NCH} 81$ & ex situ & Ncham Member, Abiod Formation & $\mathrm{CC} 23$ & Diatoscalpellum curvatum & NHMM 2019032 & tergum & Figured & & Fig $5 \mathrm{P}$ \\
\hline TUC 025 & $\mathrm{RC}$ & RCN 126 & ex situ & Mzita Marls or Aïn Settara Marls & CC25 or 26 & Diatoscalpellum curvatum & NHMM 2019033 & scutum & Figured & & Fig $5 \mathrm{~K}$ \\
\hline $\begin{array}{l}\text { TUC } 026 \\
\text { TUC } 026\end{array}$ & $\begin{array}{l}\mathrm{RC} \\
\mathrm{RC}\end{array}$ & $\begin{array}{l}\text { RCN } 135 \\
\text { RCN } 135\end{array}$ & $\begin{array}{l}\text { ex situ } \\
\text { ex situ }\end{array}$ & $\begin{array}{l}\text { Mzita Marls or Aïn Settara Marls } \\
\text { Mzita Marls or Ain Settara Marls }\end{array}$ & $\begin{array}{l}\mathrm{CC} 25 \text { or } 26 \\
\mathrm{CC} 25 \text { or } 26\end{array}$ & $\begin{array}{l}\text { Pachyscalpellum heltzeli } \\
\text { Pachyscalpellum heltzeli }\end{array}$ & $\begin{array}{l}\text { NHMM } 2015 \text { 020w } \\
\text { NHMM } 2015020 \mathrm{x}\end{array}$ & $\begin{array}{l}\text { right tergum } \\
\text { carina }\end{array}$ & $\begin{array}{l}\text { Holotype } \\
\text { Figured }\end{array}$ & $\begin{array}{l}\text { Fig } 3 \mathrm{G} \\
\text { Fig } 3 \text { P-Q }\end{array}$ & Fig $7 \mathrm{M}, \mathrm{N}$ \\
\hline TUC 026 & $\mathrm{RC}$ & RCN 135 & ex situ & Mzita Marls or Aïn Settara Marls & CC25 or 26 & Pachyscalpellum heltzeli & NHMM 2015 020y & carina & & & \\
\hline TUC 026 & $\mathrm{RC}$ & RCN 135 & ex situ & Mzita Marls or Ain Settara Marls & CC25 or 26 & Cretiscalpellum robaszynskii & NHMM 2019029 & tergum & Paratype & & Fig 5 B \\
\hline TUC 026 & $\mathrm{RC}$ & RCN 135 & ex situ & Mzita Marls or Aïn Settara Marls & CC25 or 26 & Cretiscalpellum robaszynskii & & tergum & & & \\
\hline
\end{tabular}

